\title{
Criticality Safety Criteria for License Review of Low-Level Waste Facilities
}

Manuscript Completed: November 1994

Date Published: March 1995

Prepared by

C. M. Hopper, R. H. Odegaarden, ${ }^{*}$ C. V Parks, P. B. Fox

Oak Ridge National Laboratory

Managed by Martin Marietta Energy Systems, Inc.

Oak Ridge National Laboratory

Oak Ridge, TN 37831-6370

\section{Prepared for}

Division of Waste Management

Office of Nuclear Material Safety and Safeguards

U.S. Nuclear Regulatory Commission

Washington, DC 20555-0001

NRC Job Code L1376

*Consultant 


\section{DISCLAIMER}

This report was prepared as an account of work sponsored by an agency of the United States Government. Neither the United States Government nor any agency thereof, nor any of their employees, make any warranty, express or implied, or assumes any legal liability or responsibility for the accuracy, completeness, or usefulness of any information, apparatus, product, or process disclosed, or represents that its use would not infringe privately owned rights. Reference herein to any specific commercial product, process, or service by trade name, trademark, manufacturer, or otherwise does not necessarily constitute or imply its endorsement, recommendation, or favoring by the United States Government or any agency thereof. The views and opinions of authors expressed herein do not necessarily state or reflect those of the United States Government or any agency thereof. 


\section{DISCLAIMER}

Portions of this document may be illegible in electronic image products. Images are produced from the best available original document. 


\begin{abstract}
This report provides recommended safety criteria for U.S. Nuclear Regulatory Commission (NRC) licensed burial facilities. These criteria have been developed with accepted and consistent nuclear criticality safety evaluation techniques. Additionally, this report provides the bases for the recommended safety criteria by documenting the evaluation methods and assumptions, and by reporting the results of all single-package and array calculations. These criteria were developed with care to ensure consistency with data and practices provided in current standards on nuclear criticality safety, as well as conformity of the criteria to applicable NRC regulations.

The recommended safety criteria are expressed in terms of surface-density spacing criteria, thereby greatly simplifying the application of license conditions for nuclear criticality safety control. This approach was used by an NRC licensee at the Barnwell waste burial facility by limiting the specific controls to the fewest number of parameters consistent with good nuclear safety practice. The use of surface-density criteria can eliminate the need for numerous license amendments for variations in package contents and specifications.
\end{abstract}




\section{CONTENTS}

ABSTRACT $\ldots \ldots \ldots \ldots \ldots \ldots \ldots \ldots \ldots \ldots \ldots \ldots \ldots \ldots \ldots \ldots \ldots \ldots$ Page

LIST OF TABLES $\ldots \ldots \ldots \ldots \ldots \ldots \ldots \ldots \ldots \ldots \ldots \ldots \ldots \ldots \ldots \ldots \ldots \ldots \ldots \ldots$

LIST OF FIGURES $\ldots \ldots \ldots \ldots \ldots \ldots \ldots \ldots \ldots \ldots \ldots \ldots \ldots \ldots \ldots \ldots \ldots \ldots$ viii

ACKNOWLEDGMENTS $\ldots \ldots \ldots \ldots \ldots \ldots \ldots \ldots \ldots \ldots \ldots \ldots \ldots \ldots \ldots$

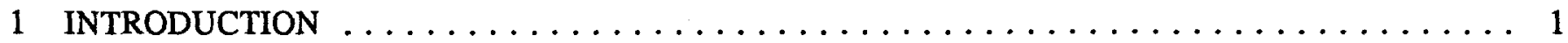

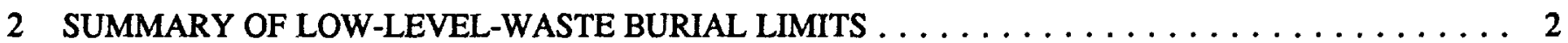

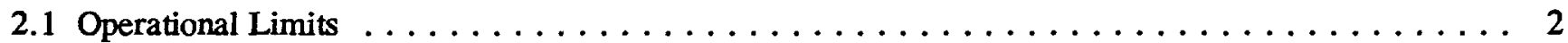

2.2 Determination of Fissile Nuclide Areal Density $\ldots \ldots \ldots \ldots \ldots \ldots \ldots \ldots \ldots \ldots$

3 REVIEW OF SURFACE-DENSITY APPROACH $\ldots \ldots \ldots \ldots \ldots \ldots \ldots \ldots \ldots \ldots$

4 DEVELOPMENT OF SAFETY CRITERIA $\ldots \ldots \ldots \ldots \ldots \ldots \ldots \ldots \ldots \ldots \ldots \ldots$

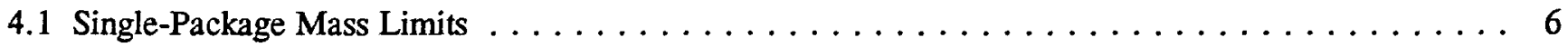

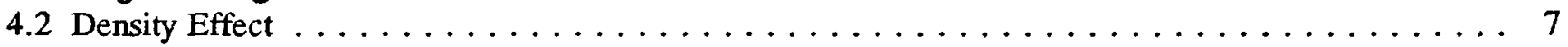

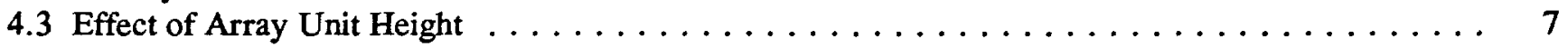

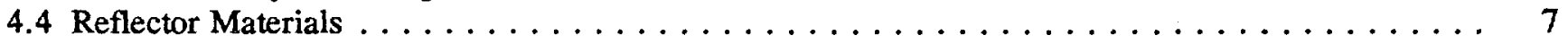

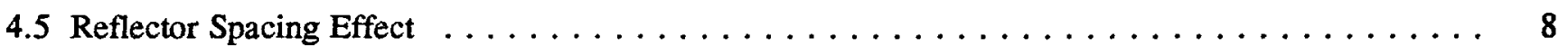

4.6 Isotopic Composition $\ldots \ldots \ldots \ldots \ldots \ldots \ldots \ldots \ldots \ldots \ldots \ldots \ldots$

4.7 Interspersed Moderation and Container Materials $\ldots \ldots \ldots \ldots \ldots \ldots \ldots \ldots$

4.8 Carbon and Beryllium Moderators $\ldots \ldots \ldots \ldots \ldots \ldots \ldots \ldots \ldots \ldots \ldots \ldots \ldots$

4.9 Array Lattice Pattern . . . . . . . . . . . . . . . . . . . . . . . . . . 9

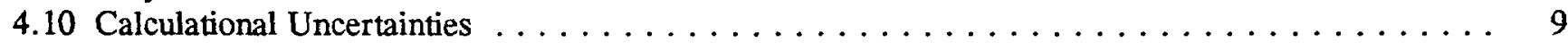

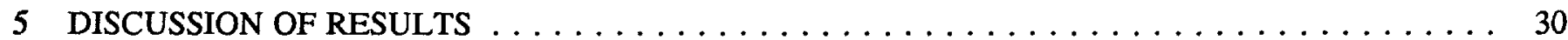

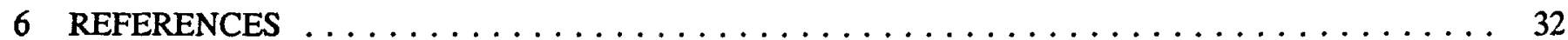




\section{LIST OF TABLES}

2.1 Summary of operational areal density limits for fissionable material in $L L W \ldots \ldots \ldots$

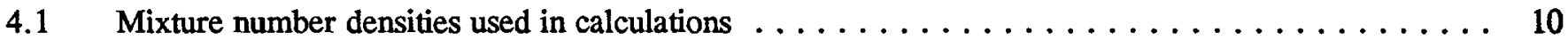

$4.2 \quad{ }^{235} \mathrm{U}$ and ${ }^{238} \mathrm{U}$ hydrogenous systems, water reflected ( $\mathrm{Z}$-axis) $\mathrm{H} / \mathrm{D}=2.5,350 \mathrm{~g}^{235} \mathrm{U}$

per unit, $\mathbf{H}{ }^{235} \mathrm{U}$ atom ratio $=744$, infinite planar array $\ldots \ldots \ldots \ldots \ldots \ldots$

$4.3 \quad{ }^{239} \mathrm{Pu}$ and ${ }^{240} \mathrm{Pu}$ hydrogenous systems, water reflected (Z-axis) $\mathrm{H} / \mathrm{D}=2.5,225 \mathrm{~g}^{239} \mathrm{Pu}$

per unit, $\mathbf{H}{ }^{239} \mathrm{Pu}$ atom ratio $=757$, infinite planar array $\ldots \ldots \ldots \ldots \ldots \ldots \ldots \ldots \ldots \ldots$

$4.4 \quad{ }^{235} \mathrm{U}(100)$ hydrogenous systems, water reflected (Z-axis), $350 \mathrm{~g}^{235} \mathrm{U}$ per unit,

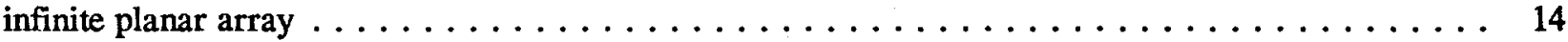

$4.5{ }^{235} \mathrm{U}(100)$ hydrogenous systems, concrete reflected (Z-axis) $350 \mathrm{~g}^{235} \mathrm{U}$ per unit,

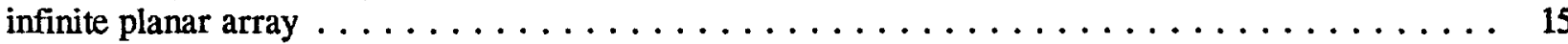

$4.6{ }^{235} \mathrm{U}(100)$ hydrogenous systems, $\mathrm{SiO}_{2}(\rho=1.9)$ reflected (Z-axis) $350 \mathrm{~g}^{235} \mathrm{U}$ per unit,

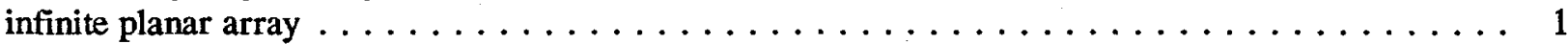

$4.7 \quad{ }^{235} \mathrm{U}(10)$ plus ${ }^{238} \mathrm{U}(90)$ hydrogenous systems, $\mathrm{SiO}_{2}(\rho=1.9)$ reflected (Z-axis) $35 \mathrm{~g}^{235} \mathrm{U}$

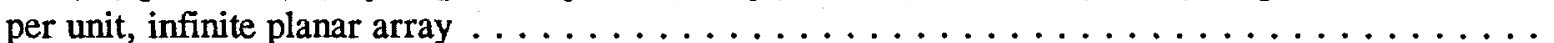

$4.8 \quad{ }^{239} \mathrm{Pu}(100)$ hydrogenous systems, water reflected (Z-axis) $225 \mathrm{~g}^{239} \mathrm{Pu}$ per unit,

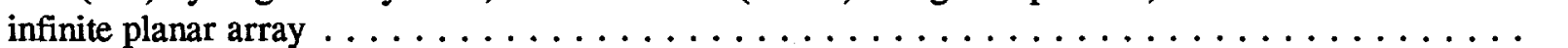

$4.9{ }^{239} \mathrm{Pu}(100)$ hydrogenous systems, concrete reflected (Z-axis) $225 \mathrm{~g}^{239} \mathrm{Pu}$ per unit, infinite planar array

$4.10{ }^{239} \mathrm{Pu}(100)$ hydrogenous systems, $\mathrm{SiO}_{2}(\mathrm{p}=1.9)$ reflected $(\mathrm{Z}$-axis $) 225 \mathrm{~g}^{229} \mathrm{Pu}$

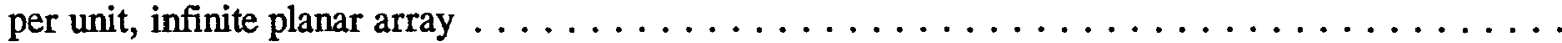

$4.11{ }^{239} \mathrm{Pu}(76)$ plus ${ }^{240} \mathrm{Pu}(12)$ and ${ }^{241} \mathrm{Pu}(12)$ hydrogenous systems, $\mathrm{SiO}_{2}(\rho=1.9)$ reflected (Z-axis) $225 \mathrm{~g}{ }^{239} \mathrm{Pu}$ per unit, infinite planar array

$4.12{ }^{235} \mathrm{U}(100)$ hydrogenous systems, soil $\left(\mathrm{SiO}_{2}\right)$ reflected (Z-axis) $\mathrm{H} / \mathrm{D}=2.5,350 \mathrm{~g}^{235} \mathrm{U}$

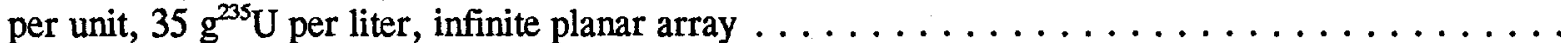

$4.13{ }^{239} \mathrm{Pu}(100)$ hydrogenous systems, soil $\left(\mathrm{SiO}_{2}\right)$ reflected (Z-axis) $\mathrm{H} / \mathrm{D}=2.5,225 \mathrm{~g}^{239} \mathrm{Pu}$ per unit, $20 \mathrm{~g}^{239} \mathrm{Pu}$ per liter, infinite planar array

$4.14{ }^{235} \mathrm{U}(100)$ hydrogenous systems, water reflected (Z-axis) $\mathrm{H} / \mathrm{D}=2.5,350 \mathrm{~g}^{235} \mathrm{U}$ per unit, $35 \mathrm{~g}^{235} \mathrm{U}$ per liter, infinite planar array

$4.15{ }^{239} \mathrm{Pu}(100)$ hydrogenous systems, water reflected (Z-axis) $\mathrm{H} / \mathrm{D}=2.5,225 \mathrm{~g}^{239} \mathrm{Pu}$ per unit, $20 \mathrm{~g}^{239} \mathrm{Pu}$ per liter, infinite planar array 
$4.16{ }^{235} \mathrm{U}$ and ${ }^{239} \mathrm{Pu}$ hydrogenous systems, water reflected (Z-axis) $\mathrm{H} / \mathrm{D}=2.5,35 \mathrm{~g}^{235} \mathrm{U}$ plus ${ }^{239} \mathrm{Pu}$ per liter, infinite planar array

$4.17{ }^{235} \mathrm{U}(100)$ hydrogenous and carbon systems, water reflected (Z-axis) $\mathrm{H} / \mathrm{D}=2.5$, $350 \mathrm{~g}^{235} \mathrm{U}$ per unit, $\mathrm{H}{ }^{235} \mathrm{U}$ atom ratio $=744$, infinite planar array

$4.18{ }^{235} \mathrm{U}(100)$ hydrogenous and beryllium systems, water reflected (Z-axis) $\mathrm{H} / \mathrm{D}=2.5$, $350 \mathrm{~g}^{235} \mathrm{U}$ per unit, $\mathrm{H} /{ }^{235} \mathrm{U}$ atom ratio $=744$, infinite planar array

4.19 Square-pitch vs triangular-pitch ${ }^{235} \mathrm{U}(100)$ hydrogenous systems, water reflected (Z-axis)

$\mathrm{H} / \mathrm{D}=2.5,350 \mathrm{~g}^{235} \mathrm{U}$ per unit, $35 \mathrm{~g}^{235} \mathrm{U}$ per liter, infinite planar array

4.20 Calculational uncertainties (maximum values for all calculations) $\ldots \ldots \ldots \ldots \ldots \ldots$

$4.21{ }^{235} \mathrm{U}(100)$ hydrogenous systems, water-reflected (Z-axis) $\mathrm{H} / \mathrm{D}=2.5,350 \mathrm{~g}^{235} \mathrm{U}$ per unit, $35 \mathrm{~g}^{235} \mathrm{U}$ per liter, infinite planar array (array pitch sensitivity)

$5.1 \quad{ }^{235} \mathrm{U}(100)$ hydrogenous systems, $350 \mathrm{~g}^{235} \mathrm{U}$ per unit, infinite planar array $\ldots \ldots \ldots \ldots \ldots$

$5.2 \quad{ }^{235} \mathrm{U}(10)$ plus ${ }^{238} \mathrm{U}(90)$ hydrogenous and homogeneous systems $35 \mathrm{~g}^{235} \mathrm{U}$ per unit,

$5.3 \quad{ }^{299} \mathrm{Pu}(100)$ hydrogenous systems, $225 \mathrm{~g}^{239} \mathrm{Pu}$ per unit, infinite planar array $\ldots \ldots \ldots \ldots \ldots$

5.4 ${ }^{239} \mathrm{Pu}(76)$ plus ${ }^{240} \mathrm{Pu}(12)$ plus ${ }^{241} \mathrm{Pu}(12)$ hydrogenous and homogeneous systems $225 \mathrm{~g}^{239} \mathrm{Pu}$ per unit, $\mathrm{H} / \mathrm{D}=1,20 \mathrm{~g}$ Pu per liter, infinite planar array 


\section{LIST OF FIGURES}

2.1 Example of an areal density determination for stacked horizontal drums. . . . . . . . . . 3

2.2 Example of an areal density determination for stacked vertical drums. $\ldots \ldots \ldots \ldots \ldots$

4.1 Critical masses of homogenous water-moderated $\mathrm{U}(93.2)$ spheres $\ldots \ldots \ldots \ldots$

4.2 Critical masses of homogenous water-moderated Pu spheres $\ldots \ldots \ldots \ldots \ldots \ldots$

4.3 Minimum critical surface-density mass per unit area for ${ }^{235} \mathrm{U}$ units $\ldots \ldots \ldots \ldots \ldots \ldots$

4.4 Minimum critical surface-density mass per unit area for ${ }^{239} \mathrm{Pu}$ units $\ldots \ldots \ldots \ldots \ldots$

4.5 Variation of possible $\mathrm{U}(100)$ operational areal density limits $\left(\mathrm{g}^{235} \mathrm{U} / \mathrm{ft}^{2}\right)$ vs burial trench soil

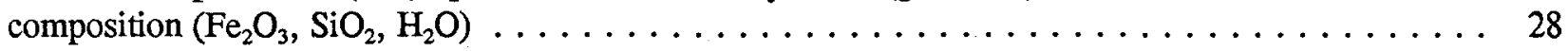

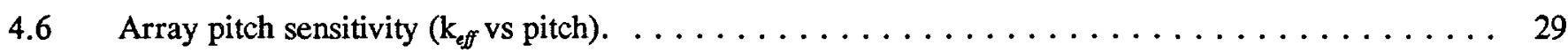




\section{ACKNOWLEDGMENTS}

The authors gratefully acknowledge the contributions and assistance of L. M. Petrie who was consulted during the formulation of this task and the preparation of the report. The authors appreciate the efforts of $R$. L. Stevenson for his insight as the principal author of Ref. 1. 


\section{INTRODUCTION}

The handling and burial of specified quantities of special nuclear material (SNM) at low-level-waste (LLW) facilities require a license from the Nuclear Regulatory Commission (NRC). With assistance from Oak Ridge National Laboratory (ORNL) staff, the NRC Office of Nuclear Material Safety and Safeguards, Low-Level-Waste and Decommissioning Projects Branch, has developed technical specifications for the nuclear criticality safety of ${ }^{235} \mathrm{U}$ and ${ }^{239} \mathrm{Pu}$ in LLW facilities. The objective of the development of these technical specifications was to establish a set of review criteria that are rigorously defensible, that can be applied uniformly to all license applications, and that conservatively ensures that buried SNM will not pose a criticality safety concern.

Since the early 1970 s, the NRC and its predecessor, the Atomic Energy Commission (AEC), have used an in-house study of surface-density spacing criteria ${ }^{1}$ for ${ }^{235} U$ as an informal basis for establishing criticality safety criteria for below-ground burial of SNM. A surface-density criterion typically specifies a fissile mass limit per package and a limiting areal density of fissile mass. Previously, the primary alternative to this approach used in licensing was to base the safety criteria on verification of the number of packages per trench, interpackage spacing, and placement of intervening material; thus, this approach leads to burial criteria that vary from license to license, depending on the respective judgments of the licensee and the NRC staff for the types of packages anticipated at the time of the license request. This alternative licensing approach resulted in the generation of numerous and differing license amendments to cover a relatively small range of variations in package contents and specifications.
The type of technical specifications for LLW burial that result from the approach used in Ref. 1 (i.e., to establish a critical criteria via a surface-density limit) were reviewed and judged to be the most suitable technical specifications for use in licensing of SNM in LLW facilities. It was judged to be most suitable for ease of understanding and application by an NRC waste burial licensee, considering current criticality safety standards and evaluation techniques. This report provides such technical specifications and licensing review criteria for LLW burial facilities for ${ }^{235} \mathrm{U}$ and ${ }^{239} \mathrm{Pu}$. Additionally, this report provides the results of the computational studies that established these technical specifications.

The physical dimensions of the limit specifications, $\mathrm{g} / \mathrm{ft}^{2}$, were chosen to be compatible with available information to LLW burial facility personnel. The gram was selected because grams are the units provided on the NRC material transfer Form 741. Square feet was selected because most personnel working at a LLW burial facility are familiar with their building, trench, bunker, etc., dimensions in terms of square feet of floor space. If need be, the conversion to $\mathrm{kg} / \mathrm{m}^{2}$ metric units may be accomplished by multiplying all $\mathrm{g} / \mathrm{ft}^{2}$ values by the constant, $0.010763\left(\mathrm{ft}^{2}-\mathrm{kg}\right) /\left(\mathrm{g}-\mathrm{m}^{2}\right)$.

Without consideration of additional controls (e.g., intervening neutron-absorbing materials, separation of storage facilities) or extended knowledge of burial environments (e.g., neutron reflector constituents, such as concrete and/or soil and possible seasonal moisture content), surface-density criteria provided in this report should be used for guidance. 


\section{SUMMARY OF LOW-LEVEL-WASTE BURIAL LIMITS}

Operational limits were determined from safety criteria and computational results provided in Section 3 and are presented below in terms of observable values, that is, LLW package fissile nuclide contents (i.e., grams of ${ }^{235} \mathrm{U}$ or grams of ${ }^{239} \mathrm{Pu}$ and grams of ${ }^{241} \mathrm{Pu}$ ) and package "foot print" in square feet.

\subsection{Operational Limits}

Without consideration for additional burial facility conditions (e.g., intervening neutron-absorbing materials, specific maximum enrichments, specific combinations with homogeneous materials) or extended knowledge of burial environments (e.g., concrete and/or soil constituents and seasonal moisture content), the operational limits developed from the surface-density criteria methodology should be used. These basic operational limits are provided in Table 2.1. These operational limits are intended for use with "low-level wastes" consisting primarily of contaminated hydrocarbons (e.g., paper, plastic, other organics, etc.), contaminated metals/alloys, and inorganics. Bulk carbon (graphite) is treated separately.

\subsection{Determination of Fissile Nuclide Areal Density}

Depending upon the type and orientation of the fissionable material containers (e.g., drums standing on ends or lying on sides, boxes or crates), fissile nuclide areal density should be determined according to the basic formulae shown in Figures 2.1 and 2.2. Where stacks of boxes or crates are used, the sum of the fissile material gram masses in a vertical stack of packages divided by the respective "foot print" of the package (i.e., package width times package length) determines the fissile nuclide areal density (i.e., mass per unit area). In no case may the calculated fissile nuclide areal density exceed values provided in Table 2.1. Allowable carbon areal densities are determined similarly.

Table 2.1 Summary of operational areal density limits for fissionable material in LLW

\begin{tabular}{|c|c|c|c|}
\hline $\begin{array}{l}\text { Fissile material type, weight percent } \\
\text { (w/o) of fissile nuclide }\end{array}$ & $\begin{array}{l}\text { Maximum mass of fissile } \\
\text { nuclide per package }\end{array}$ & $\begin{array}{c}\text { Maximum fissile } \\
\text { nuclide areal } \\
\text { density }^{b}\end{array}$ & $\begin{array}{c}\text { Maximum } \\
\text { bulk carbon } \\
\text { areal density }^{\mathbf{b}}\end{array}$ \\
\hline$\leq 100 \mathrm{~W} / 0{ }^{235} \mathrm{U}$ & $350 \mathrm{~g}^{235} \mathrm{U}$ & $94 \mathrm{~g}^{235} \mathrm{U} / \mathrm{ft}^{2}$ & $1880 \mathrm{~g} \mathrm{C}^{\prime} \mathrm{ft}^{2}$ \\
\hline$\leq 10 \mathrm{w} / \mathrm{o}^{235} \mathrm{U}+290 \mathrm{w} / \mathrm{o}{ }^{238} \mathrm{U}$ & $350 \mathrm{~g}{ }^{235} \mathrm{U}$ & $174 \mathrm{~g}^{235} \mathrm{U} / \mathrm{ft}^{2}$ & $3480 \mathrm{~g} \mathrm{C} / \mathrm{ft}^{2}$ \\
\hline$\leq 100 \mathrm{w} / \mathrm{o}{ }^{239} \mathrm{Pu}$ & $225 \mathrm{~g}^{239} \mathrm{Pu}$ & $52 \mathrm{~g}{ }^{239} \mathrm{Pu} / \mathrm{ft}^{2}$ & c \\
\hline $\begin{array}{l}\leq 76 \mathrm{w} / \mathrm{o}^{239} \mathrm{Pu}+212 \mathrm{w} / \mathrm{o}^{240} \mathrm{Pu}+ \\
\leq 12 \mathrm{w} / \mathrm{o}^{241} \mathrm{Pu}\end{array}$ & $225 \mathrm{~g}^{239} \mathrm{Pu}+35 \mathrm{~g}^{241} \mathrm{Pu}$ & $\begin{array}{l}\left(51 \mathrm{~g}^{239} \mathrm{Pu}+8 \mathrm{~g}\right. \\
\left.{ }^{241} \mathrm{Pu}\right) / \mathrm{ft}^{2}\end{array}$ & c \\
\hline
\end{tabular}

- For a given fissile material type all three limits (i.e., grams fissile nuclide per container, fissile nuclide areal density, and bulk carbon areal density) must be ensured.

b The areal density in $\mathrm{kg} / \mathrm{m}^{2}$ can be obtained by multiplying the $\mathrm{g} / \mathrm{ft}^{2}$ values by 0.010763 .

c Packages with bulk carbon are outside the scope of these suggested criteria and must be considered on a case-by-case basis. 


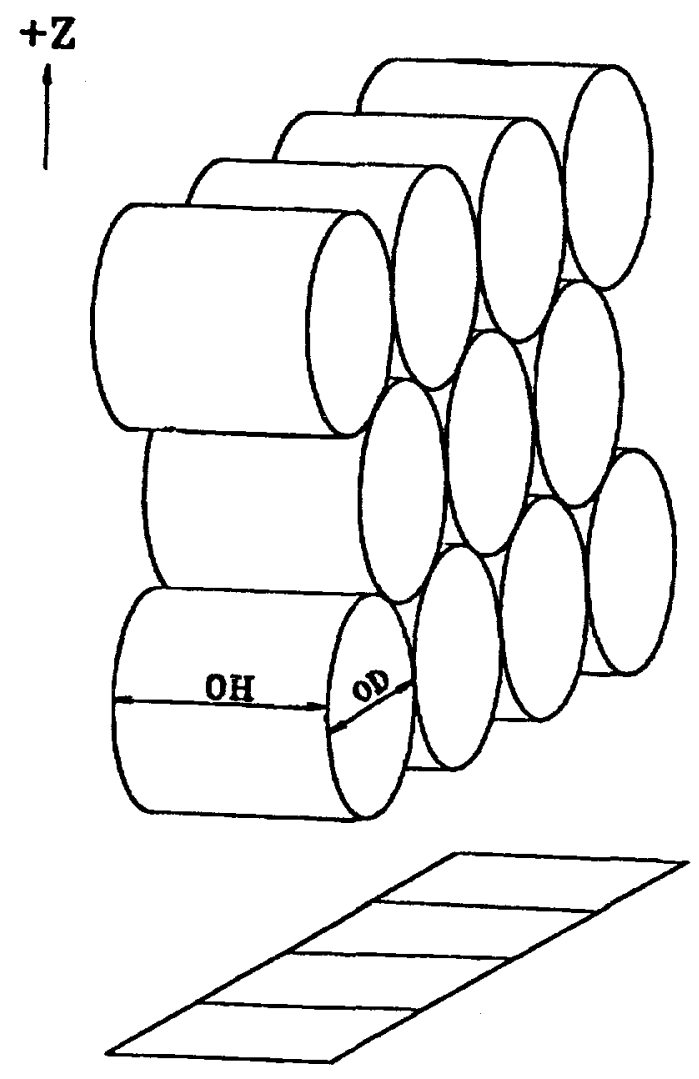

Assuming 55-gal tight-head drum

$$
\begin{aligned}
& \mathrm{OD}=1.914 \mathrm{ft}(22.97 \text { in.) } \\
& \mathrm{OH}=2.896 \mathrm{ft} \text { (34.75 in.) }
\end{aligned}
$$

Given 3 layers of drums $(\mathrm{N}=3$ drums) at $145 \mathrm{~g}{ }^{235} \mathrm{U} /$ drum $\left(\mathrm{M}=145 \mathrm{~g}^{235} \mathrm{U} / \mathrm{drum}\right)$ with no bulk beryllium or carbon

$$
\frac{(\mathrm{N})(\mathrm{M})}{(\mathrm{OD})(\mathrm{OH})}-\frac{\mathrm{g}}{\mathrm{ft}^{2}}
$$

$\frac{(3 \text { layers of drums })\left(145 \mathrm{~g}^{235} \mathrm{U} / \text { drum }\right)}{(1.914 \mathrm{ft})(2.896 \mathrm{ft})}=\frac{78.4 \mathrm{~g}^{25} \mathrm{U}}{\mathrm{ft}^{2}}$

$$
\begin{aligned}
\mathrm{M} & =\text { fissile isotope mass (grams per drum) } \\
\mathrm{N} & =\text { number of layers of drums } \\
\mathrm{OD} & =\text { drum effective outside diameter in feet } \\
\mathrm{OH} & =\text { drum effective outside height in feet }
\end{aligned}
$$

Footprint of one horizontal drum is $(\mathrm{OD})(\mathrm{OH})$

Figure 2.1 Example of an areal density determination for stacked horizontal drums 


$$
\begin{array}{r}
\text { Assuming 55-gal tight-head drum } \\
\mathrm{OD}=1.914 \mathrm{ft}(22.97 \mathrm{in} .) \\
\mathrm{OH}=2.896 \mathrm{ft}(34.75 \text { in.) }
\end{array}
$$
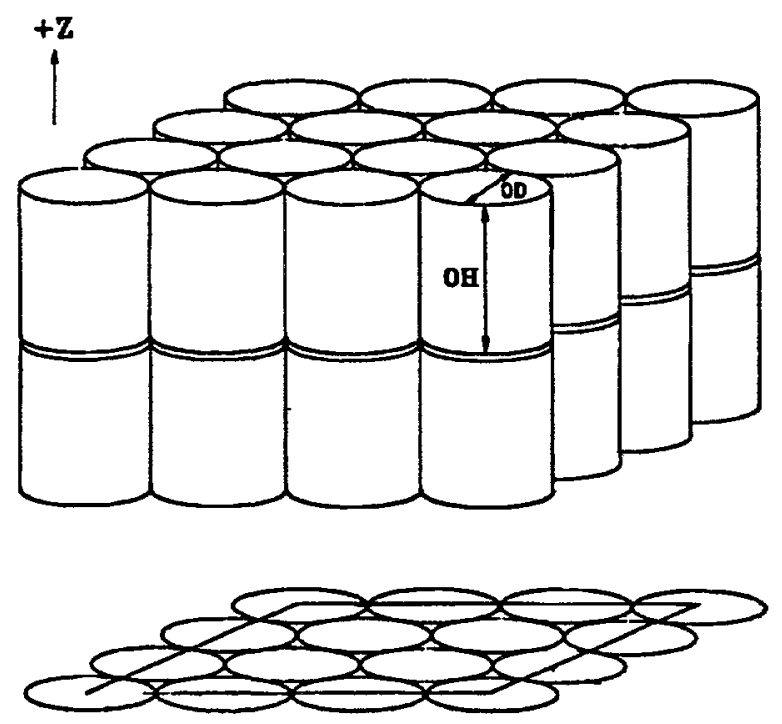

Given 2 layers of drums ( $N=2$ drums) at $125 \mathrm{~g}^{235} \mathrm{U} /$ drum $\left(\mathrm{M}=125 \mathrm{~g}^{235} \mathrm{U} /\right.$ drum $)$ with no bulk beryllium or carbon

$$
\begin{gathered}
\frac{(\mathrm{N})(\mathrm{M})}{(0.866)(\mathrm{OD})^{2}}=\frac{\mathrm{g}}{\mathrm{ft}^{2}} \\
\frac{(2 \text { layers of drums })\left(125 \mathrm{~g}^{255} \mathrm{U} / \mathrm{drum}\right)}{(0.866)\left(1.914 \mathrm{ft}^{2}\right)}=\frac{78.8 \mathrm{~g}^{255} \mathrm{U}}{\mathrm{ft}^{2}}
\end{gathered}
$$

Footprint of one vertically positioned drum in a triangularpitched array is $(0.866)(\mathrm{OD})^{2}$

$$
\begin{aligned}
\mathbf{M} & =\text { fissile isotope mass (grams per drum) } \\
\mathbf{N} & =\text { number of layers of drums } \\
\mathrm{OD} & =\text { drum effective outside diameter in feet } \\
\mathrm{OH} & =\text { drum effective outside height in feet }
\end{aligned}
$$

Figure 2.2 Example of an areal density determination for stacked veritical drums 


\section{REVIEW OF SURFACE-DENSITY APPPROACH}

In 1961, H. C. Paxton noted a relationship between the mass of fissile material per unit base area (i.e., surface density) in a critical, air-spaced plane array of discrete units and the critical mass per unit area of a uniform slab of the same material. ${ }^{2}$ It was later sugested that the relationship be used to establish safe spacing criteria for planar arrays. ${ }^{3}$ The resulting surface-density approach is simple: develop a limit on the fissile mass allowed per unit area (generally taken perpendicular to the axes of the arrayed units) such that a planar array of the most reactive units planned for the array will remain safely subcritical. Given the nature of long-term placement or burial of low-level waste (LLW) (i.e., the potential for package and conents settling), the surface density specifications for allowable fissile material masses per unit area must be applied to the level base area upon which the waste containers rest (e.g., the floor area of the storage area).

The surface-density study of Ref. 1 was directed at fuel fabrication plant layout and was adapted to the burial of LLW in cylindrical packages containing optimally moderated ${ }^{255} \mathrm{U}$ solutions. Container walls and liners were ignored in the calculations. The study included calculations to investigate the effects of (1) ${ }^{235} \mathrm{U}$ density, (2) fraction critical (i.e., ratio of the mass of a single unit to the bare critical mass of the same fissile material in a similar shape), (3) cylindrical geometry, (4) reflector proximity, and (5) array size. The study indicated that further work should be done to consider other variables such as (1) isotopic composition, (2) interspersed moderation and container materials, (3) array lattice patterns, (4) reflector materials, and (5) array size. Each of the above parameters (and possibly others) should be investigated to ensure that a safe areal density value is established for all normal and abnormal circumstances that might arise in the handling and burial of fissile material at LLW facilities. Though the surface-density approach permits vertical displacement of fissile material, it must be noted that horizontal migration of the fissile material after placement in storage or burial environments is not considered. A critical configuration of fissile material can be postulated for almost any burial site if unconstrained migration of SNM is assumed.

The surface-density approach is applicable for developing safety criteria for discrete units (containers) buried in a planar array lattice. Other methods that prescribe "volume-density" limits, thus allowing multiple layers of planar arrays, have been developed and applied for storage arrays." The volume density approach is very flexible and allows a more optimal use of land, but the burial in more than one plane could increase the probability that migration of SNM would pose a safety concern. The complexity and limited use of the volume-density approach relative to the surface-density approach eliminated it as the recommended approach to use in this study. 


\section{DEVELOPMENT OF SAFETY CRITERIA}

This study was directed at the burial of LLW materials in packages which follows the normal method of handling the waste materials. Therefore, the study concentrated on planar arrays of packages. The burial of loose bulk LLW materials is outside the scope of this study.

The surface-density spacing criteria developed in this report is based on analyses that utilize state-of-the-art computational tools and data. In particular, the latest version of the well-established SCALE code system ${ }^{5}$ was used, together with a cross-section library ${ }^{6}$ processed from Version V of the Evaluated Nuclear Data File. The SCALE criticality safety analysis sequences (CSAS) were used to calculate the planar array spacings that provide a "critical" neutron multiplication factor $\left(k_{e f f}\right)$ of 1.0. The CSAS module uses the BONAMI-S and NITAWL-II codes for problemdependent resonance processing of the cross sections and the KENO V.a code to calculate the $\mathrm{k}_{\text {eff }}$ value using statistical Monte Carlo techniques. An automated search algorithm in the CSAS module was typically used to evaluate the critical array spacing. This code system and data library have recently been validated for use in a wide range of criticality safety analyses. $^{\text {? }}$

The set of calculations used to determine the surfacedensity spacing criteria also considered the effect of each of the parameters discussed in Sects. 4.1-4.10 for ${ }^{235} \mathrm{U}$ and ${ }^{239} \mathrm{Pu}$ systems. The effect of these parameters was evaluated using calculational models of both single cylindrical units and infinite planar arrays of cylindrical units. For a selected fissile mass concentration, the single-unit mass limit fixed the volume of the cylinder. Then with this volume and a selected height-to-diameter (H/D) ratio, the dimensions of the cylinder could be established. In the planar array analyses the center-to-center spacing (or pitch) for the units was varied to determine the pitch that resulted in a calculated critical value for the system.

For all array calculations using light water or concrete as the reflector, the reflector thicknesses were taken to be $30 \mathrm{~cm}$ and $61 \mathrm{~cm}$, respectively. For the array calcu-lations using $\mathrm{SiO}_{2}$ (soil) as the reflector, the $\mathrm{SiO}_{2}$ was assumed to be $240 \mathrm{~cm}$ thick. Except as noted in
Section 4.5, there was no gap between the plane array units and the reflector. A partial listing of number densities for various mixtures used in all the analyses is given in Table 4.1.

\subsection{Single-Package Mass Limits}

Prudent application of the surface-density approach would ensure that each discrete unit (waste package) is in its most reactive configuration. The supporting analyses used in this study are based on applying a safety margin to single-package mass limits corresponding to the minimum critical mass for hydrogenous reflected and moderated spheres. Using reported critical data ${ }^{8}$ (in particular, Figures 10 and 31 in Ref. 8) and a safety margin of 2.3 (to account for accidental double-batching of material plus uncertainties), the single mass limits are $350 \mathrm{~g}$ for ${ }^{235} \mathrm{U}$ and $225 \mathrm{~g}$ for ${ }^{239} \mathrm{Pu}$. These limits are consistent with the single parameter limits for uniform aqueous solutions as provided in ANSI/ANS-8.1. ${ }^{9}$ The study of Ref. 1 only considered light-water moderation of each package. A limited investigation was performed to determine if beryllium and/or carbon moderation or commingling would increase the single-unit reactivity and so decrease the recommended single-unit mass limits. The results are given in Sect. 4.8, which does recommend limits on the amount of carbon that may be present in waste packages containing ${ }^{235} \mathrm{U}$. Results of the beryllium studies demonstrated a reduction in allowable areal densities for both uranium and pluonium LLW. Additionally, the inclusion of bulk carbon with plutonium-contaminated LLW showed a similar reduction in allowable areal densities.

A basic requirement for the application of the surfacedensity technique is that the mass fraction critical be 0.3 or less. Assuming the use of the water-moderated, single-package mass limits, the fraction critical value would be 0.3 or less for each mass limit. For ${ }^{235} \mathrm{U}(93.2)$, the fraction critical is approximately 0.27 and is obtained by dividing the single-package limit by the minimum critical mass $(\sim 1,300 \mathrm{~g})$ of a bare (unreflected) spherical system [see Figure 4.1 (upper curve of Figure 10 in Ref. 8)]. For ${ }^{239} \mathrm{Pu}$, the fraction critical is approximately 0.24 and is obtained by dividing the single-package limit by the minimum critical 
mass $(\sim 930 \mathrm{~g})$ of a bare spherical system [see Figure 4.2 (upper curve of Figure 31 in Ref. 8)].

The reactivity of a single unit is reduced if either the isotope ${ }^{238} \mathrm{U}$ or ${ }^{240} \mathrm{Pu}$ is present within the package. This reduced reactivity can be seen in Tables 4.2 and 4.3.

\subsection{Density Effect}

Calculations were made using fissile material densities that ranged from 15 through $300 \mathrm{~g}^{235} \mathrm{U}$ per liter and 10 through $300 \mathrm{~g}{ }^{239} \mathrm{Pu}$ per liter for light-water-, concrete-, and $\mathrm{SiO}_{2}$ (soil)-reflected critical planar arrays. The calculations are reported in Tables 4.4 through 4.11. Densities higher or lower than these values would decrease the reactivity of the system, as can be seen in Figures 4.3 and 4.4. The concentrations resulting in the smallest surface density ranged from $35-50 \mathrm{~g}$ per liter for ${ }^{235} \mathrm{U}$ systems and $20-25 \mathrm{~g}$ per liter for ${ }^{239} \mathrm{Pu}$ systems.

\subsection{Effect of Array Unit Height}

Calculations were made to demonstrate the effect that the H/D ratios of individual units in the arrays have on the reactivity of the systems. The range of values considered were $H / D=1$ to $H / D=4$ (in one case, 6 for low-enriched uranium). The results can be seen in Tables 4.4 through 4.11 for ${ }^{235} \mathrm{U}$ and ${ }^{239} \mathrm{Pu}$ critical hydrogenous systems reflected by light water, concrete, and $\mathrm{SiO}_{2}$ (soil). The optimum $\mathrm{H} / \mathrm{D}$ ratio ranged between 1.0 and 2.5 for both ${ }^{235} \mathrm{U}$ and ${ }^{239} \mathrm{Pu}$ systems. The minimum critical value for each single unit concentration has been plotted in Figures 4.3 and 4.4 for the calculated values reported in Tables 4.4 through 4.10 (regardless of $H / D$ ratio for which it was calculated). Thus, the seven curves in Figures 4.3 and 4.4 represent the minimum critical surface-density mass per unit area (isotopic composition vs reflector material).

\subsection{Reflector Materials}

Concrete, beryllium, or carbon (graphite) as a reflector material would increase the reactivity of a planar array (X,Y-axes) reflected with light water in the Z-axis. However, it is not expected that beryllium or carbon will be present as reflectors in a waste burial site. Tables 4.3 through 4.4 and 4.8 and 4.9 show the results of calculations for ${ }^{235} \mathrm{U}$ and ${ }^{239} \mathrm{Pu}$ planar arrays reflected with light water and concrete as a function of the fissile concentration of the individual units and their $\mathrm{H} / \mathrm{D}$ ratios.

Analyses also have been done to investigate whether soil can be a better reflector than water or concrete for the planar array configurations. The composition of soil can vary widely from location to location, and the moisture content varies from season to season. Therefore, worst-case soil conditions were assumed for the study, that is dry $\mathrm{SiO}_{2}$ and $\mathrm{SiO}_{2}$ with saturated moisture content. Based on a referenced upper limit, ${ }^{10}$ the density of the $\mathrm{SiO}_{2}$ was assumed to be $1.9 \mathrm{~g} / \mathrm{cm}^{3}$ for dry, packed sand and gravel. A second case was calculated assuming the $\mathrm{SiO}_{2}$, at the same density (1.9), to be water saturated. The water-saturated $\mathrm{SiO}_{2}$ reflector provided an array reactivity approaching that of the concrete reflected array. The water-saturated $\mathrm{SiO}_{2}$ results are shown in Tables 4.12 and 4.13 for ${ }^{235} \mathrm{U}$ and ${ }^{239} \mathrm{Pu}$ systems, respectively. The results shown in Tables 4.6, 4.7, 4.10, and 4.11 and Figures 4.3 and 4.4 for ${ }^{235} \mathrm{U}$ and ${ }^{239} \mathrm{Pu}$ systems, respectively, demonstrate that dry $\mathrm{SiO}_{2}$ as a reflector material yields a more reactive system than water or concretereflected systems. The results in Tables 4.6, 4.7, 4.10, 4.11, 4.12, and 4.13 and Figures 4.3 and 4.4 are conservative because actual soil will contain unquantifiable amounts of water moisture, organic materials, iron, and other materials that will absorb neutrons and make the array less reactive.

To qualitatively demonstrate the relative importance of evaluating specific reflector conditions, a study was performed that consisted of a series of calculations for a highly moderated infinite slab of ${ }^{235} U$ reflected on both sides with 2 -m-thick reflectors composed of homogeneous mixtures of water, silicon dioxide, and ferric oxide in various volume percents. Results of the calculations are presented in Figure 4.5. As can be seen from the figure, a pure silicon dioxide reflector is the most restrictive condition (i.e., $\sim 80 \mathrm{~g}^{235} \mathrm{U} / \mathrm{ft}^{2}$ ) whereas approximately a $70 \mathrm{vol} \% \mathrm{H}_{2} \mathrm{O}$ and $30 \mathrm{vol} \%$ ferric oxide reflector is the least restrictive $\left(\sim 180 \mathrm{~g}^{235} \mathrm{U} / \mathrm{ft}^{2}\right)$. 


\subsection{Reflector Spacing Effect}

The surface-density study of Ref. 1 indicates that the position of the reflector from the top and bottom of the array does not affect the reactivity of a large $(1000 \times$ $1000 \times 1)$ slab-like array of SNM. This assumption was verified in this study by making one calculation for a ${ }^{235} \mathrm{U}$ array and a second for a ${ }^{239} \mathrm{Pu}$ array $(\mathrm{X}, \mathrm{Y}$ axes), which demonstrated that placement of the reflector in an infinite planar array does not affect the reactivity of the array (see Tables 4.14 and 4.15 ). In these calculations, the normally tight-fitting reflector in the $\pm Z$-axis directions was displaced 6 in. from the top and bottom of the arrays.

\subsection{Isotopic Composition}

The isotopes studied included ${ }^{235} \mathrm{U}$ and ${ }^{239} \mathrm{Pu}$. The isotope ${ }^{233} \mathrm{U}$ was excluded because it exists in very limited quantities outside Department of Energy (DOE) facilities. One calculation was made to demonstrate that less than fully enriched uranium $(80 \mathrm{wt} \%$ ${ }^{235} \mathrm{U}$ ) decreases the reactivity of the array (see Table 4.2). : A second calculation demonstrated that the presence of ${ }^{240} \mathrm{Pu}(20 \mathrm{wt} \%)$ in ${ }^{239} \mathrm{Pu}(80 \mathrm{wt} \%)$ decreases the reactivity of the array (see Table 4.3).

The array calculations using $\mathrm{SiO}_{2}$ as a reflector resulted in low surface-density values when compared with water- and concrete-reflected arrays, and the radioactive material composition contains only fissile isotopes (see Tables 4.6, 4.7, 4.10, and 4.11 and Figures 4.3 and 4.4). Therefore, additional calculations were performed for low-enriched, homogeneous uranium systems containing $10 \mathrm{wt} \%{ }^{235} \mathrm{U}$ and $90 \mathrm{wt} \%{ }^{238} \mathrm{U}$, and homogeneous plutonium systems containing 76 wt $\%{ }^{239} \mathrm{Pu}, 12$ wt $\%{ }^{240} \mathrm{Pu}$ and $12 \mathrm{wt} \%$ ${ }^{241} \mathrm{Pu}$, when reflected by $\mathrm{SiO}_{2}$. These results are reported in Tables 4.7 and 4.11 and Figures 4.3 and 4.4. These isotopic compositions are expected to bound that found in commercial nuclear activities and provide higher surface-density limits.

The mixing of ${ }^{235} \mathrm{U}$ and ${ }^{239} \mathrm{Pu}$ isotopes in individual units and arrays can be done safely if the limits for ${ }^{239} \mathrm{Pu}$ hydrogenous systems are controlling. This situa- tion is demonstrated in Table 4.16, where $50 \%$ of the single-unit masses for ${ }^{235} \mathrm{U}$ and ${ }^{239} \mathrm{Pu}$ are combined and yield a surface-density limit that is halfway between the previous individual calculations.

\subsection{Interspersed Moderation and Container Materials}

The presence of steel in these types of assumed wellmoderated systems reduces $k_{\text {eff }}$ due to thermal neutron absorption. For the burial facility, the presence of the steel containers cannot be guaranteed. The presence of 12-gauge or 1/4-in.-thick carbon-steel containers between units in arrays always resulted in less-reactive arrays (see Tables 4.14 and 4.15) because of neutron absorption in iron. The effect of interspersed moderation (1/4-in.- and 1.0-in.-thick water radially around each unit) on optimally moderated ${ }^{235} U$ and ${ }^{239} \mathrm{Pu}$ hydrogenous array units is shown in Tables 4.14 and 4.15 to reduce the reactivity of the arrays. The presence of 1/4-in.- or 1-in.-thick lead (a neutron scatterer) shielding material between units in arrays resulted in equal or less-reactive arrays (see Tables 4.14 and 4.15). The effect of dry $\mathrm{SiO}_{2}$ (also a neutron scatterer) filling the voids between optimally spaced units resulted in equal or less-reactive arrays (see Tables 4.14 and 4.15). Wet $\mathrm{SiO}_{2}$ between units would only reduce the array reactivity because of the presence of water.

\subsection{Carbon and Beryllium Moderators}

Table 4.17 illustrates that for ${ }^{235} \mathrm{U}$ systems (which were performed for a hydrogen-to-fissile nuclide atom ratio, $\mathrm{H} / \mathrm{X}$, of 744) the total mass of carbon (graphite) present in a unit (package) should not exceed 20 times the total mass of the ${ }^{235} \mathrm{U}$ that may be present. Table 4.18 illustrates that for ${ }^{235} \mathrm{U}$ systems, the total mass of beryllium present in a unit (package) tends to continually reduce the allowable surface density of ${ }^{235} U$, thereby demonstrating the need to evaluate such containers on a case-by-case basis. 


\subsection{Array Lattice Pattern}

Because the square-pitched spacing between units is optimized, it is not expected that a triangular-pitch lattice pattern could result in a significantly more reactive array than the square-pitch lattice pattern. The effect of using a triangular-pitch versus a squarepitch array lattice is shown in Table 4.19.

\subsection{Calculational Uncertainties}

From Table 4.20 it can be seen that the calculational uncertainty is $0.0530 \Delta \mathrm{k}$. This total uncertainty includes uncertainties for values calculated above
1.00 , a statistical uncertainty of $2 \sigma$ (due to the uncertainty in the Monte Carlo calculations), crosssection uncertainties of $0.02^{7}$ and an assumed $0.02 \Delta \mathrm{k}$ allowance to ensure subcriticality of the calculated array. Using this uncertainty of $0.0530 \Delta \mathrm{k}$, a subcritical limit of 0.9453 can be determined (subcritical limit, $k_{\text {eff }}=0.99830 .0530=0.9453$, where $\mathrm{k}_{\text {eff }}=0.9983$ is assumed critical). Applying this value of 0.9453 to a plot of Table 4.21 data (see Figure 4.6), the pitch of the array increased from 31.148 to $34.5 \mathrm{~cm}$. Therefore, any calculated critical surface-density value should be reduced by $20 \%$ to ensure subcriticality. 
Development

Table 4.1 Mixture number densities used in calculations (partial list)

\begin{tabular}{|c|c|c|}
\hline Mixture & $\begin{array}{c}\text { Density } \\
(\mathrm{g} / \mathrm{cc})\end{array}$ & $\begin{array}{l}\text { Number density } \\
\text { (atoms/barn-cm) }\end{array}$ \\
\hline \multirow[t]{2}{*}{ Water } & 0.9982 & $H=0.066743$ \\
\hline & & $\mathrm{O}=0.033372$ \\
\hline \multirow[t]{10}{*}{ Concrete } & 2.3 & $\mathbf{H}=0.0085$ \\
\hline & & $C=0.0202$ \\
\hline & & $0=0.0355$ \\
\hline & & $\mathrm{Ca}=0.0111$ \\
\hline & & $\mathrm{Si}=0.0017$ \\
\hline & & $\mathrm{Mg}=0.00186$ \\
\hline & & $\mathrm{Fe}=0.000193$ \\
\hline & & $\mathrm{Al}=0.000556$ \\
\hline & & $K=0.0000403$ \\
\hline & & $\mathrm{Na}=0.0000163$ \\
\hline \multirow[t]{2}{*}{$\mathrm{SiO}_{2}$, dry } & 1.9 & $\mathrm{Si}=0.0190459$ \\
\hline & & $\mathrm{O}=0.0380919$ \\
\hline \multirow[t]{3}{*}{$\mathrm{SiO}_{2}$, water saturated } & 2.08 & $\mathrm{Si}=0.0190459$ \\
\hline & & $\mathrm{O}=0.0440995$ \\
\hline & & $\mathrm{H}=0.0120153$ \\
\hline \multirow[t]{3}{*}{${ }^{235} \mathrm{U}(100)$} & 0.035 & ${ }^{235} U=8.96745-5$ \\
\hline & & $H=0.0667514$ \\
\hline & & $\mathrm{O}=0.0333757$ \\
\hline \multirow[t]{3}{*}{${ }^{239} \mathrm{Pu}(100)$} & 0.020 & ${ }^{239} \mathrm{Pu}=5.03834-5$ \\
\hline & & $\mathbf{H}=0.0667514$ \\
\hline & & $\mathrm{O}=0.0333757$ \\
\hline
\end{tabular}




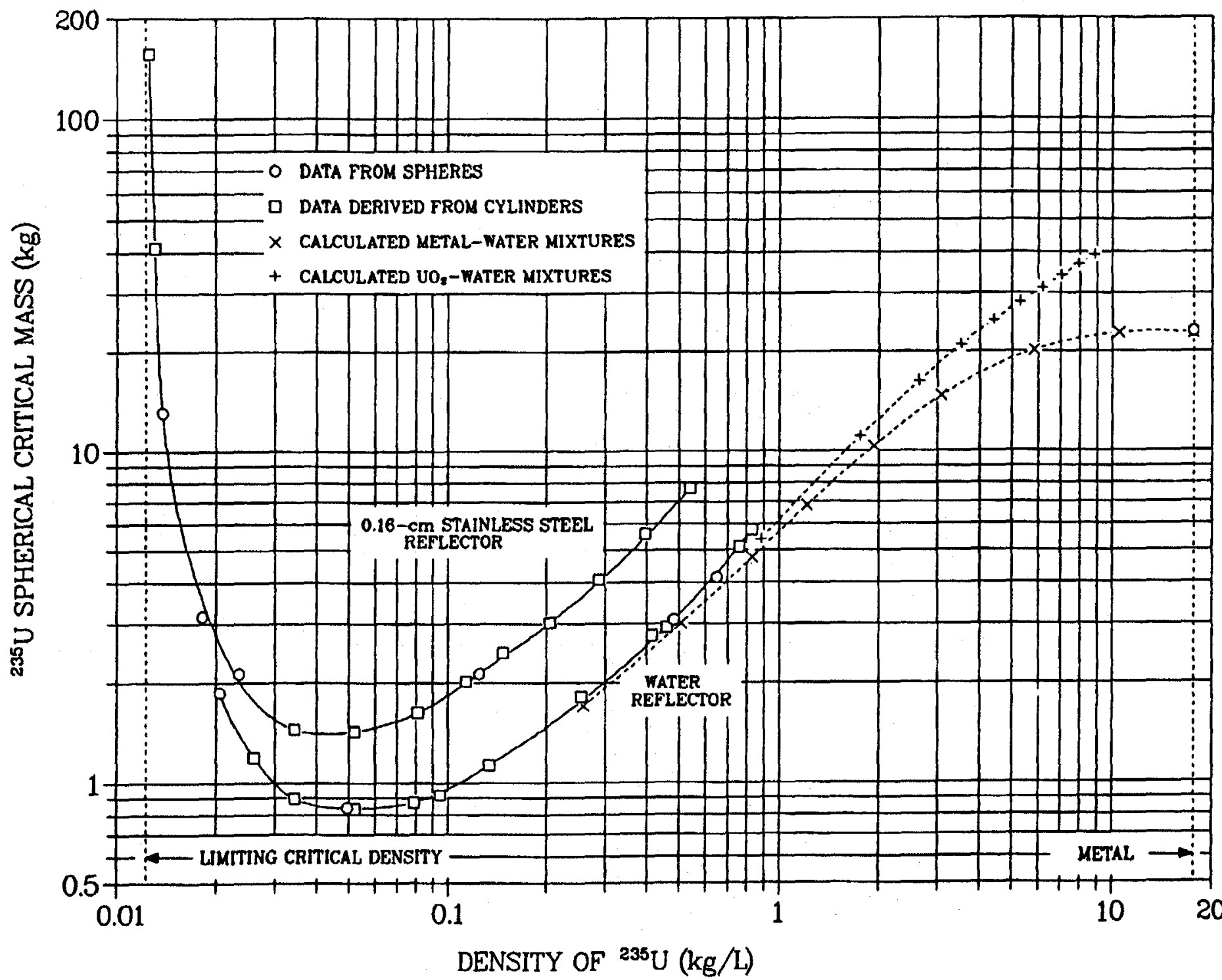

Figure 4.1 Critical masses of homogeneous water-moderated U(93.2) spheres. Solution data appear unless indicated otherwise (Taken from Figure 10 of Ref. 8) 


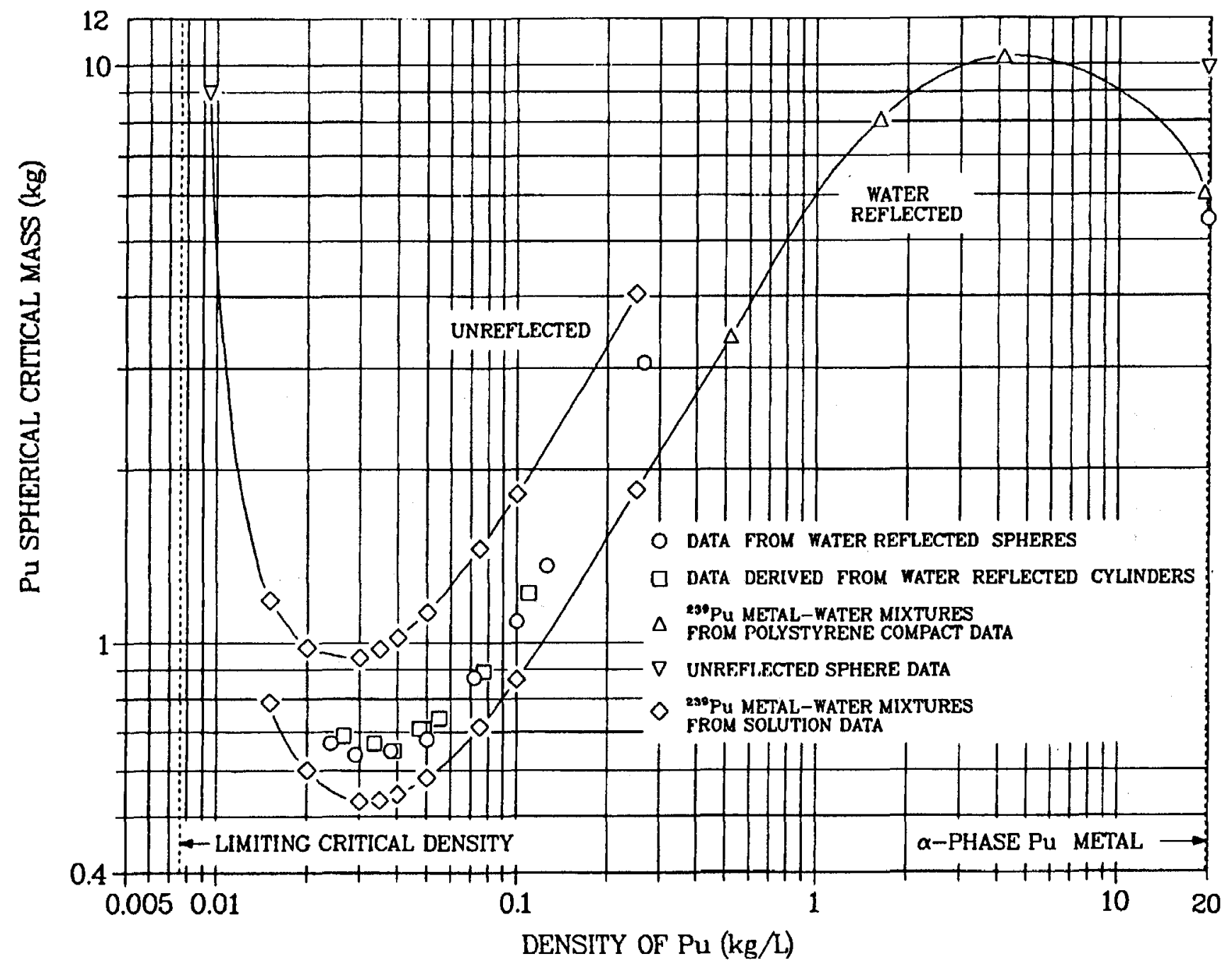

Figure 4.2 Critical masses of homogeneous water-moderated Pu spheres. Solution data appear unless indicated otherwise (Taken from Figure 31 of Ref. 8) 
Table 4.2 ${ }^{235} \mathrm{U}$ and ${ }^{238} \mathrm{U}$ hydrogenous systems, water-reflected (Z-axis) $\mathrm{H} / \mathrm{D}=\mathbf{2 . 5}$, $350 \mathrm{~g}^{235} \mathrm{U}$ per unit, $\mathrm{H}{ }^{235} \mathrm{U}$ atom ratio $=744$, infinite planar array

\begin{tabular}{ccccc}
\hline Case & Pitch $(\mathrm{cm})$ & $\mathrm{k}_{\text {eff }}$ & $\sigma$ & {$\left[\mathrm{g}\left({ }^{235} \mathrm{U}\right) / \mathrm{ft}^{2}\right]^{\mathrm{a}}$} \\
\hline Base, no ${ }^{238} \mathrm{U}$ & 31.148 & 0.9983 & 0.0019 & 335 \\
${ }^{235} \mathrm{U}(80),{ }^{288} \mathrm{U}(20)$ & 25.07 & 1.0018 & 0.0016 & 517 \\
\hline
\end{tabular}

${ }^{2}$ The areal density in $\mathrm{kg} / \mathrm{m}^{2}$ can be obtained by multiplying the $\mathrm{g} / \mathrm{ft}^{2}$ values by 0.010763 .

Table 4.3 ${ }^{239} \mathrm{Pu}$ and ${ }^{240} \mathrm{Pu}$ hydrogenous systems, water-reflected (Z-axis) $\mathrm{H} / \mathrm{D}=\mathbf{2 . 5}$, $225 \mathrm{~g}^{239} \mathrm{Pu}$ per unit, $\mathrm{H} /{ }^{239} \mathrm{Pu}$ atom ratio $=757$, infinite planar array

\begin{tabular}{ccccc}
\hline Case & Pitch $(\mathrm{cm})$ & \multicolumn{1}{c}{$\mathrm{k}_{\text {eff }}$} & $\sigma$ & {$\left[\mathrm{g}\left({ }^{239} \mathrm{Pu}\right) / \mathrm{ft}^{2}\right]^{\mathrm{a}}$} \\
\hline $\begin{array}{c}\text { Base, no }{ }^{240} \mathrm{Pu} \\
{ }^{239} \mathrm{Pu}(80),{ }^{240} \mathrm{Pu}(20)\end{array}$ & 32.532 & 1.0012 & 0.0019 & 198 \\
\hline
\end{tabular}

The areal density in $\mathrm{kg} / \mathrm{m}^{2}$ can be obtained by multiplying the $\mathrm{g} / \mathrm{ft}^{2}$ values by 0.010763 . 
Development

Table 4.4 ${ }^{235} \mathrm{U}(\mathbf{1 0 0})$ hydrogenous systems, water-reflected (Z-axis), $350 \mathrm{~g}^{235} \mathrm{U}$ per unit, infinite planar array

\begin{tabular}{|c|c|c|c|c|c|}
\hline $\mathrm{H} / \mathrm{D}$ & $\mathrm{g}^{235} \mathrm{U} / \mathrm{L}$ & Pitch $(\mathrm{cm})$ & $\mathbf{k}_{\text {eff }}$ & $\sigma$ & {$\left[\mathrm{g}^{235} \mathrm{U} / \mathrm{ft}^{2}\right]^{\mathrm{a}}$} \\
\hline \multirow[t]{5}{*}{1.5} & 100 & 25.844 & 1.0036 & 0.0022 & 487 \\
\hline & 75 & 28.16 & 0.9990 & 0.0025 & 410 \\
\hline & 50 & 30.416 & 1.0045 & 0.0022 & 351 \\
\hline & 35 & 30.676 & 1.0046 & 0.0021 & 346 \\
\hline & 25 & 29.484 & 1.0005 & 0.0017 & 374 \\
\hline \multirow[t]{6}{*}{2.0} & 300 & 16.9554 & 0.9996 & 0.0026 & 1131 \\
\hline & 100 & 25.996 & 0.9999 & 0.0023 & 481 \\
\hline & 75 & 28.16 & 0.9995 & 0.0022 & 410 \\
\hline & 50 & 30.416 & 1.0026 & 0.0020 & 351 \\
\hline & 35 & 31.218 & 1.0003 & 0.0018 & 334 \\
\hline & 25 & 29.484 & 1.0043 & 0.0018 & 374 \\
\hline \multirow[t]{7}{*}{2.5} & 300 & 16.8448 & 1.0024 & 0.0023 & 1146 \\
\hline & 100 & 25.844 & 0.9981 & 0.0022 & 487 \\
\hline & 75 & 28.158 & 0.9984 & 0.0024 & 410 \\
\hline & 50 & 30.416 & 0.9968 & 0.0018 & 351 \\
\hline & 35 & 31.148 & 0.9983 & 0.0019 & 335 \\
\hline & 25 & 29.486 & 1.0028 & 0.0016 & 374 \\
\hline & 15 & 22.88 & 0.9975 & 0.0012 & 621 \\
\hline \multirow[t]{7}{*}{3.0} & 300 & 16.9998 & 1.0001 & 0.0025 & 1125 \\
\hline & 100 & 25.592 & 1.0021 & 0.0023 & 496 \\
\hline & 75 & 27.862 & 1.0046 & 0.0022 & 419 \\
\hline & 50 & 30.414 & 0.9968 & 0.0022 & 352 \\
\hline & 35 & 30.874 & 1.0007 & 0.0021 & 341 \\
\hline & 25 & 29.44 & 1.0023 & 0.0017 & 375 \\
\hline & 15 & 22.344 & 1.0008 & 0.0012 & 651 \\
\hline \multirow[t]{5}{*}{4.0} & 100 & 25.45 & 1.0020 & 0.0023 & 502 \\
\hline & 75 & 27.666 & 0.9993 & 0.0022 & 425 \\
\hline & 50 & 29.886 & 0.9977 & 0.0019 & 364 \\
\hline & 35 & 30.438 & 1.0022 & 0.0017 & 351 \\
\hline & 25 & 29.484 & 1.0036 & 0.0015 & 374 \\
\hline
\end{tabular}

"The areal density in $\mathrm{kg} / \mathrm{m}^{2}$ can be obtained by multiplying the $\mathrm{g} / \mathrm{ft}^{2}$ values by 0.010763 . 
Table 4.5 ${ }^{235} \mathrm{U}(100)$ hydrogenous systems, concrete-reflected (Z-axis) $350 \mathrm{~g}^{225} \mathrm{U}$ per unit, infinite planar array

\begin{tabular}{|c|c|c|c|c|c|}
\hline $\mathrm{H} / \mathrm{D}$ & $\mathrm{g}^{235} \mathrm{U} / \mathrm{L}$ & Pitch $(\mathrm{cm})$ & $\mathbf{k}_{\text {eff }}$ & $\sigma$ & {$\left[\mathrm{g}^{235} \mathrm{U} / \mathrm{ft}^{2}\right]^{\mathrm{a}}$} \\
\hline \multirow[t]{5}{*}{1.0} & 100 & 33.244 & 1.0045 & 0.0023 & 294 \\
\hline & 75 & 35.574 & 1.0041 & 0.0022 & 257 \\
\hline & 50 & 37.522 & 1.0048 & 0.0020 & 231 \\
\hline & 35 & 37.124 & 1.0037 & 0.0020 & 236 \\
\hline & 25 & 34.418 & 0.9968 & 0.0016 & 274 \\
\hline \multirow[t]{5}{*}{1.5} & 100 & 32.870 & 0.9992 & 0.0024 & 301 \\
\hline & 75 & 35.266 & 1.0018 & 0.0023 & 261 \\
\hline & 50 & 37.866 & 1.0006 & 0.0020 & 227 \\
\hline & 35 & 36.944 & 1.0032 & 0.0019 & 238 \\
\hline & 25 & 34.478 & 0.9999 & 0.0017 & 274 \\
\hline \multirow[t]{6}{*}{2.0} & 100 & 32.52 & 1.0033 & 0.0024 & 307 \\
\hline & 75 & 35.028 & 1.0004 & 0.0020 & 265 \\
\hline & 50 & 36.952 & 1.0037 & 0.0022 & 238 \\
\hline & 35 & 37.66 & 0.9964 & 0.0018 & 229 \\
\hline & 25 & 34.666 & 0.9967 & 0.0017 & 271 \\
\hline & 15 & 24.582 & 0.9983 & 0.0012 & 538 \\
\hline \multirow[t]{6}{*}{2.5} & 100 & 32.164 & 1.0008 & 0.0022 & 315 \\
\hline & 75 & 34.292 & 1.0039 & 0.0022 & 277 \\
\hline & 50 & 36.634 & 1.0010 & 0.0020 & 242 \\
\hline & 35 & 36.98 & 1.0005 & 0.0019 & 238 \\
\hline & 25 & 34.326 & 1.0023 & 0.0015 & 276 \\
\hline & 15 & 24.352 & 0.9998 & 0.0012 & 548 \\
\hline \multirow[t]{6}{*}{3.0} & 100 & 31.548 & 1.0045 & 0.0022 & 327 \\
\hline & 75 & 33.774 & 1.0044 & 0.0021 & 285 \\
\hline & 50 & 36.39 & 0.9976 & 0.0019 & 246 \\
\hline & 35 & 36.848 & 1.0019 & 0.0018 & 239 \\
\hline & 25 & 34.454 & 0.9972 & 0.0016 & 274 \\
\hline & 15 & 23.976 & 0.9990 & 0.0014 & 566 \\
\hline \multirow[t]{5}{*}{4.0} & 100 & 31.23 & 1.0028 & 0.0023 & 333 \\
\hline & 75 & 33.44 & 1.0038 & 0.0021 & 291 \\
\hline & 50 & 35.75 & 1.0034 & 0.0019 & 254 \\
\hline & 35 & 36.128 & 0.9981 & 0.0017 & 249 \\
\hline & 25 & 33.754 & 0.9998 & 0.0017 & 285 \\
\hline
\end{tabular}

The areal density in $\mathrm{kg} / \mathrm{m}^{2}$ can be obtained by multiplying the $\mathrm{g} / \mathrm{ft}^{2}$ values by 0.010763 . 
Development

Table 4.6 ${ }^{235} \mathrm{U}(100)$ hydrogenous systems, $\mathrm{SiO}_{2}(\rho=1.9)$-reflected (Z-axis) $350 \mathrm{~g}^{235} \mathrm{U}$ per unit, infinite planar array

\begin{tabular}{|c|c|c|c|c|c|}
\hline $\mathrm{H} / \mathrm{D}$ & $\mathrm{g}^{235} \mathrm{U} / \mathrm{L}$ & Pitch $(\mathrm{cm})$ & $\mathbf{k}_{\text {eff }}$ & 0 & {$\left[\mathrm{~g}^{235} \mathrm{U} / \mathrm{ft}^{2}\right]^{\mathrm{a}}$} \\
\hline \multirow[t]{5}{*}{1.0} & 100 & 43.066 & 1.0034 & 0.0027 & 175 \\
\hline & 75 & 45.826 & 1.0024 & 0.0026 & 155 \\
\hline & 50 & 49.716 & 0.9960 & 0.0023 & 132 \\
\hline & 35 & 48.946 & 0.9995 & 0.0021 & 136 \\
\hline & 25 & 43.324 & 1.0018 & 0.0018 & 173 \\
\hline \multirow[t]{5}{*}{1.5} & 100 & 43.288 & 0.9966 & 0.0026 & 174 \\
\hline & 75 & 45.636 & 1.0033 & 0.0026 & 156 \\
\hline & 50 & 48.898 & 1.0040 & 0.0024 & 136 \\
\hline & 35 & 48.704 & 0.9968 & 0.0021 & 137 \\
\hline & 25 & 43.288 & 1.0037 & 0.0017 & 174 \\
\hline \multirow[t]{6}{*}{2.0} & 100 & 42.11 & 1.0036 & 0.0029 & 183 \\
\hline & 75 & 45.738 & 0.9969 & 0.0025 & 155 \\
\hline & 50 & 48.404 & 1.0028 & 0.0023 & 139 \\
\hline & 35 & 47.89 & 1.0000 & 0.0022 & 142 \\
\hline & 25 & 43.142 & 1.0030 & 0.0018 & 175 \\
\hline & 15 & 26.28 & 1.0047 & 0.0014 & 470 \\
\hline \multirow[t]{6}{*}{2.5} & 100 & 42.526 & 0.9965 & 0.0026 & 180 \\
\hline & 75 & 45.222 & 0.9984 & 0.0024 & 159 \\
\hline & 50 & 48.192 & 0.9972 & 0.0022 & 140 \\
\hline & 35 & 46.916 & 1.0045 & 0.0020 & 148 \\
\hline & 25 & 42.87 & 1.0012 & 0.0019 & 177 \\
\hline & 15 & 26.246 & 1.0028 & 0.0012 & 472 \\
\hline
\end{tabular}

The areal density in $\mathrm{kg} / \mathrm{m}^{2}$ can be obtained by multiplying the $\mathrm{g} / \mathrm{ft}^{2}$ values by 0.010763 . 
Table 4.7 ${ }^{235} \mathrm{U}(10)$ plus ${ }^{238} \mathrm{U}(90)$ hydrogenous systems, $\mathrm{SiO}_{2}(\rho=1.9)$-reflected (Z-axis) $35 \mathrm{~g}^{235} \mathrm{U}$ per unit, infinite planar array

\begin{tabular}{|c|c|c|c|c|c|}
\hline$H / D$ & $g^{235} U / L$ & Pitch (cm) & $\mathbf{k}_{\text {eff }}$ & $\sigma$ & {$\left[\mathrm{g}^{235} \mathrm{U} / \mathrm{ft}^{2}\right]^{\mathrm{a}}$} \\
\hline \multirow[t]{5}{*}{1.0} & 100 & 10.5078 & 0.9969 & 0.0023 & 294 \\
\hline & 75 & 11.057 & 0.9994 & 0.0021 & 266 \\
\hline & 50 & 11.4704 & 1.0000 & 0.0020 & 247 \\
\hline & 35 & 11.5204 & 0.9956 & 0.0019 & 245 \\
\hline & 25 & & & & not critical \\
\hline \multirow[t]{5}{*}{2.0} & 100 & 10.482 & 0.9991 & 0.0023 & 295 \\
\hline & 75 & 11.1716 & 0.9962 & 0.0020 & 260 \\
\hline & 50 & 11.5854 & 1.0008 & 0.0018 & 242 \\
\hline & 35 & 11.4686 & 0.9955 & 0.0018 & 247 \\
\hline & 25 & 10.6972 & 0.9971 & 0.0016 & 284 \\
\hline \multirow[t]{5}{*}{4.0} & 100 & 10.4872 & 0.9991 & 0.0023 & 295 \\
\hline & 75 & 11.0418 & 1.0043 & 0.0021 & 266 \\
\hline & 50 & 11.5588 & 0.9999 & 0.0020 & 243 \\
\hline & 35 & 11.401 & 1.0007 & 0.0017 & 250 \\
\hline & 25 & 10.5782 & 1.0005 & 0.0016 & 290 \\
\hline \multirow[t]{5}{*}{6.0} & 100 & 10.4208 & 1.0044 & 0.0021 & 299 \\
\hline & 75 & 11.063 & 0.9979 & 0.0021 & 265 \\
\hline & 50 & 11.574 & 0.9976 & 0.0019 & 242 \\
\hline & 35 & 11.4202 & 1.0006 & 0.0017 & 249 \\
\hline & 25 & 10.535 & 0.9986 & 0.0015 & 293 \\
\hline
\end{tabular}

The areal density in $\mathrm{kg} / \mathrm{m}^{2}$ can be obtained by multiplying the $\mathrm{g} / \mathrm{ft}^{2}$ values by 0.010763 . 
Development

Table 4.8 ${ }^{239} \mathrm{Pu}(100)$ hydrogenous systems, water-reflected (Z-axis) $225 \mathrm{~g}^{239} \mathrm{Pu}$ per unit, infinite planar array

\begin{tabular}{|c|c|c|c|c|c|}
\hline $\mathrm{H} / \mathrm{D}$ & $\mathrm{g}^{239} \mathrm{Pu} / \mathrm{L}$ & Pitch $(\mathrm{cm})$ & $\mathbf{k}_{\text {eff }}$ & 0 & {$\left[\mathrm{~g}^{239} \mathrm{Pu} / \mathrm{ft}^{2}\right]^{\mathrm{a}}$} \\
\hline \multirow[t]{5}{*}{1.0} & 50 & 27.104 & 1.0042 & 0.0022 & 285 \\
\hline & 35 & 30.48 & 0.9988 & 0.0021 & 225 \\
\hline & 25 & 31.244 & 0.9969 & 0.0021 & 214 \\
\hline & 20 & 31.354 & 1.0028 & 0.0019 & 213 \\
\hline & 15 & 30.372 & 0.9999 & 0.0017 & 227 \\
\hline \multirow[t]{6}{*}{2.0} & 50 & 28.012 & 1.0025 & 0.0021 & 266 \\
\hline & 35 & 30.882 & 0.9980 & 0.0022 & 219 \\
\hline & 25 & 32.23 & 1.0039 & 0.0039 & 201 \\
\hline & 20 & 32.532 & 1.0024 & 0.0021 & 198 \\
\hline & 15 & 31.2 & 1.0016 & 0.0017 & 215 \\
\hline & 10 & 26.288 & 0.9984 & 0.0014 & 302 \\
\hline \multirow[t]{9}{*}{2.5} & 300 & 13.419 & 1.0036 & 0.0025 & 1161 \\
\hline & 100 & 21.776 & 1.0006 & 0.0024 & 441 \\
\hline & 75 & 24.308 & 1.0009 & 0.0023 & 354 \\
\hline & 50 & 27.87 & 1.0037 & 0.0023 & 269 \\
\hline & 35 & 30.48 & 1.0049 & 0.0021 & 225 \\
\hline & 25 & 32.182 & 0.9991 & 0.0021 & 201 \\
\hline & 20 & 32.532 & 1.0012 & 0.0019 & 198 \\
\hline & 15 & 31.17 & 0.9989 & 0.0017 & 215 \\
\hline & 10 & 26.148 & 0.9983 & 0.0015 & 305 \\
\hline \multirow[t]{6}{*}{3.0} & 50 & 28.016 & 0.9961 & 0.0024 & 266 \\
\hline & 35 & 30.48 & 1.0008 & 0.0020 & 225 \\
\hline & 25 & 31.884 & 1.0044 & 0.0018 & 206 \\
\hline & 20 & 32.532 & 0.9971 & 0.0018 & 198 \\
\hline & 15 & 30.862 & 1.0011 & 0.0017 & 219 \\
\hline & 10 & 26.094 & 0.9962 & 0.0013 & 307 \\
\hline \multirow[t]{6}{*}{4.0} & 50 & 27.456 & 1.0006 & 0.0024 & 277 \\
\hline & 35 & 30.48 & 1.9979 & 0.0023 & 225 \\
\hline & 25 & 31.532 & 1.0027 & 0.0020 & 210 \\
\hline & 20 & 32.03 & 1.0027 & 0.0019 & 203 \\
\hline & 15 & 30.844 & 1.0030 & 0.0020 & 220 \\
\hline & 10 & 25.598 & 0.9991 & 0.0015 & 319 \\
\hline
\end{tabular}

The areal density in $\mathrm{kg} / \mathrm{m}^{2}$ can be obtained by multiplying the $\mathrm{g} / \mathrm{ft}^{2}$ values by 0.010763 . 
Table $4.9{ }^{239} \mathrm{Pu}(100)$ hydrogenous systems, concrete-reflected (Z-axis) $225 \mathrm{~g}^{239}$ Pu per unit, infinite planar array

\begin{tabular}{|c|c|c|c|c|c|}
\hline H/D & $\mathrm{g}^{239} \mathrm{Pu} / \mathrm{L}$ & Pitch (cm) & $k_{\text {eff }}$ & 0 & {$\left[\mathrm{~g}^{239} \mathrm{Pu} / \mathrm{ft}^{2}\right]^{\mathrm{a}}$} \\
\hline \multirow[t]{5}{*}{1.0} & 50 & 36.322 & 1.0038 & 0.0020 & 158 \\
\hline & 35 & 39.82 & 0.9975 & 0.0022 & 132 \\
\hline & 25 & 40.28 & 1.0045 & 0.0021 & 129 \\
\hline & 20 & 39.684 & 1.0006 & 0.0019 & 133 \\
\hline & 15 & 36.38 & 1.0011 & 0.0017 & 158 \\
\hline \multirow[t]{6}{*}{2.0} & 50 & 35.264 & 1.0011 & 0.0022 & 168 \\
\hline & 35 & 38.538 & 0.9982 & 0.0021 & 141 \\
\hline & 25 & 39.926 & 0.9967 & 0.0019 & 131 \\
\hline & 20 & 39.05 & 1.0029 & 0.0019 & 137 \\
\hline & 15 & 36.64 & 1.0017 & 0.0017 & 156 \\
\hline & 10 & 28.668 & 1.0017 & 0.0013 & 254 \\
\hline \multirow[t]{8}{*}{2.5} & 100 & 27.918 & 0.9964 & 0.0024 & 268 \\
\hline & 75 & 30.668 & 0.9952 & 0.0023 & 222 \\
\hline & 50 & 34.812 & 0.9971 & 0.0023 & 172 \\
\hline & 35 & 37.696 & 1.0025 & 0.0020 & 147 \\
\hline & 25 & 39.094 & 0.9981 & 0.0017 & 137 \\
\hline & 20 & 38.824 & 1.0008 & 0.0019 & 139 \\
\hline & 15 & 35.872 & 1.0031 & 0.0016 & 162 \\
\hline & 10 & 28.564 & 1.0022 & 0.0013 & 256 \\
\hline \multirow[t]{6}{*}{3.0} & 50 & 34.54 & 1.0022 & 0.0022 & 175 \\
\hline & 35 & 37.552 & 0.9951 & 0.0021 & 148 \\
\hline & 25 & 38.844 & 0.9975 & 0.0021 & 139 \\
\hline & 20 & 38.40 & 0.9976 & 0.0019 & 142 \\
\hline & 15 & 36.722 & 0.9961 & 0.0016 & 155 \\
\hline & 10 & 28.55 & 1.0036 & 0.0013 & 256 \\
\hline \multirow[t]{6}{*}{4.0} & 50 & 34.13 & 1.0011 & 0.0023 & 179 \\
\hline & 35 & 36.846 & 1.0020 & 0.0019 & 154 \\
\hline & 25 & 38.212 & 1.0001 & 0.0020 & 143 \\
\hline & 20 & 38.676 & 1.0034 & 0.0018 & 140 \\
\hline & 15 & 36.042 & 0.9995 & 0.0017 & 161 \\
\hline & 10 & 28.386 & 0.9995 & 0.0011 & 259 \\
\hline
\end{tabular}

${ }^{a}$ The areal density in $\mathrm{kg} / \mathrm{m}^{2}$ can be obtained by multiplying the $\mathrm{g} / \mathrm{ft}^{2}$ values by 0.010763 . 
Development

Table 4.10 ${ }^{239} \mathrm{Pu}(100)$ hydrogenous systems, $\mathrm{SiO}_{2}(\rho=1.9)$-reflected (Z-axis) $225 \mathrm{~g}^{239} \mathrm{Pu}$ per unit, infinite planar array

\begin{tabular}{|c|c|c|c|c|c|}
\hline $\mathrm{H} / \mathrm{D}$ & $\mathrm{g}^{239} \mathrm{Pu} /$ liter & Pitch (cm) & $k_{\text {eff }}$ & o & {$\left[\mathrm{g}^{239} \mathrm{Pu} / \mathrm{ft}^{2}\right]^{\mathrm{a}}$} \\
\hline \multirow[t]{7}{*}{1.0} & 100 & 37.822 & 0.9973 & 0.0028 & 146 \\
\hline & 75 & 41.856 & 1.0041 & 0.0028 & 119 \\
\hline & 50 & 47.206 & 1.0030 & 0.0026 & 93 \\
\hline & 35 & 51.490 & 1.0037 & 0.0026 & 79 \\
\hline & 25 & 53.390 & 0.9996 & 0.0021 & 73 \\
\hline & 20 & 52.302 & 0.9977 & 0.0019 & 76 \\
\hline & 15 & 46.748 & 1.0038 & 0.0020 & 96 \\
\hline \multirow[t]{8}{*}{2.0} & 100 & 37.366 & 1.0038 & 0.0026 & 150 \\
\hline & 75 & 41.334 & 1.0011 & 0.0028 & 122 \\
\hline & 50 & 46.592 & 1.0040 & 0.0027 & 96 \\
\hline & 35 & 50.652 & 0.9980 & 0.0022 & 81 \\
\hline & 25 & 51.932 & 1.0039 & 0.0022 & 78 \\
\hline & 20 & 51.356 & 0.9976 & 0.0019 & 79 \\
\hline & 15 & 47.326 & 0.9968 & 0.0019 & 93 \\
\hline & 10 & 33.528 & 1.0017 & 0.0013 & 186 \\
\hline \multirow[t]{6}{*}{2.5} & 50 & 46.224 & 1.0014 & 0.0026 & 98 \\
\hline & 35 & 49.852 & 1.0019 & 0.0024 & 84 \\
\hline & 25 & 51.478 & 0.9987 & 0.0021 & 79 \\
\hline & 20 & 50.298 & 0.9995 & 0.0021 & 83 \\
\hline & 15 & 46.428 & 1.0001 & 0.0019 & 97 \\
\hline & 10 & 33.508 & 1.0013 & 0.0014 & 186 \\
\hline
\end{tabular}

The areal density in $\mathrm{kg} / \mathrm{m}^{2}$ can be obtained by multiplying the $\mathrm{g} / \mathrm{ft}^{2}$ values by 0.010763 . 
Table 4.11 ${ }^{239} \mathrm{Pu}(76)$ plus ${ }^{240} \mathrm{Pu}(12)$ and ${ }^{241} \mathrm{Pu}(12)$ hydrogenous systems, $\mathrm{SiO}_{2}(\rho=1.9)$ reflected (Z-axis) $225 \mathrm{~g}^{239} \mathrm{Pu}$ per unit, infinite planar array

\begin{tabular}{|c|c|c|c|c|c|c|}
\hline $\mathrm{H} / \mathrm{D}$ & $\mathrm{g}^{239} \mathrm{Pu} / \mathrm{L}$ & Pitch (cm) & $\mathbf{k}_{\text {eff }}$ & {$\left[\mathrm{g}^{239} \mathrm{Pu} / \mathrm{ft}^{2}\right]^{\mathrm{a}}$} & $\sigma$ & {$\left[\mathrm{g}\left({ }^{239} \mathrm{Pu}+{ }^{241} \mathrm{Pu}\right) / \mathrm{ft}^{2}\right]^{2}$} \\
\hline \multirow[t]{7}{*}{1.0} & 100 & 33.870 & 0.9968 & 182 & 0.0029 & 211 \\
\hline & 75 & 38.318 & 0.9988 & 142 & 0.0026 & 164 \\
\hline & 50 & 44.568 & 1.0005 & 105 & 0.0023 & 122 \\
\hline & 35 & 49.422 & 1.0043 & 86 & 0.0025 & 100 \\
\hline & 25 & 52.532 & 1.0050 & 76 & 0.0022 & 88 \\
\hline & 20 & 53.912 & 0.9990 & 72 & 0.0021 & 83 \\
\hline & 15 & 51.888 & 0.9981 & 78 & 0.0018 & 90 \\
\hline \multirow[t]{8}{*}{2.0} & 100 & 33.934 & 0.9979 & 182 & 0.0026 & 211 \\
\hline & 75 & 38.376 & 0.9955 & 142 & 0.0026 & 164 \\
\hline & 50 & 44.240 & 1.0046 & 107 & 0.0024 & 124 \\
\hline & 35 & 49.346 & 0.9999 & 86 & 0.0022 & 100 \\
\hline & 25 & 52.334 & 1.0016 & 76 & 0.0022 & 88 \\
\hline & 20 & 52.000 & 1.0036 & 77 & 0.0021 & 89 \\
\hline & 15 & 50.450 & 1.0026 & 82 & 0.0017 & 95 \\
\hline & 10 & 40.680 & 1.0024 & 126 & 0.0014 & 146 \\
\hline \multirow[t]{6}{*}{2.5} & 50 & 43.750 & 1.0018 & 109 & 0.0023 & 126 \\
\hline & 35 & 48.472 & 1.0013 & 89 & 0.0022 & 103 \\
\hline & 25 & 51.794 & 0.9965 & 78 & 0.0021 & 90 \\
\hline & 20 & 51.784 & 1.0005 & 78 & 0.0020 & 90 \\
\hline & 15 & 49.866 & 1.0039 & 84 & 0.0019 & 97 \\
\hline & 10 & 40.274 & 1.0018 & 129 & 0.0015 & 149 \\
\hline
\end{tabular}

\footnotetext{
${ }^{2}$ The areal density in $\mathrm{kg} / \mathrm{m}^{2}$ can be obtained by multiplying the $\mathrm{g} / \mathrm{ft}^{2}$ values by 0.010763 .
} 
Development

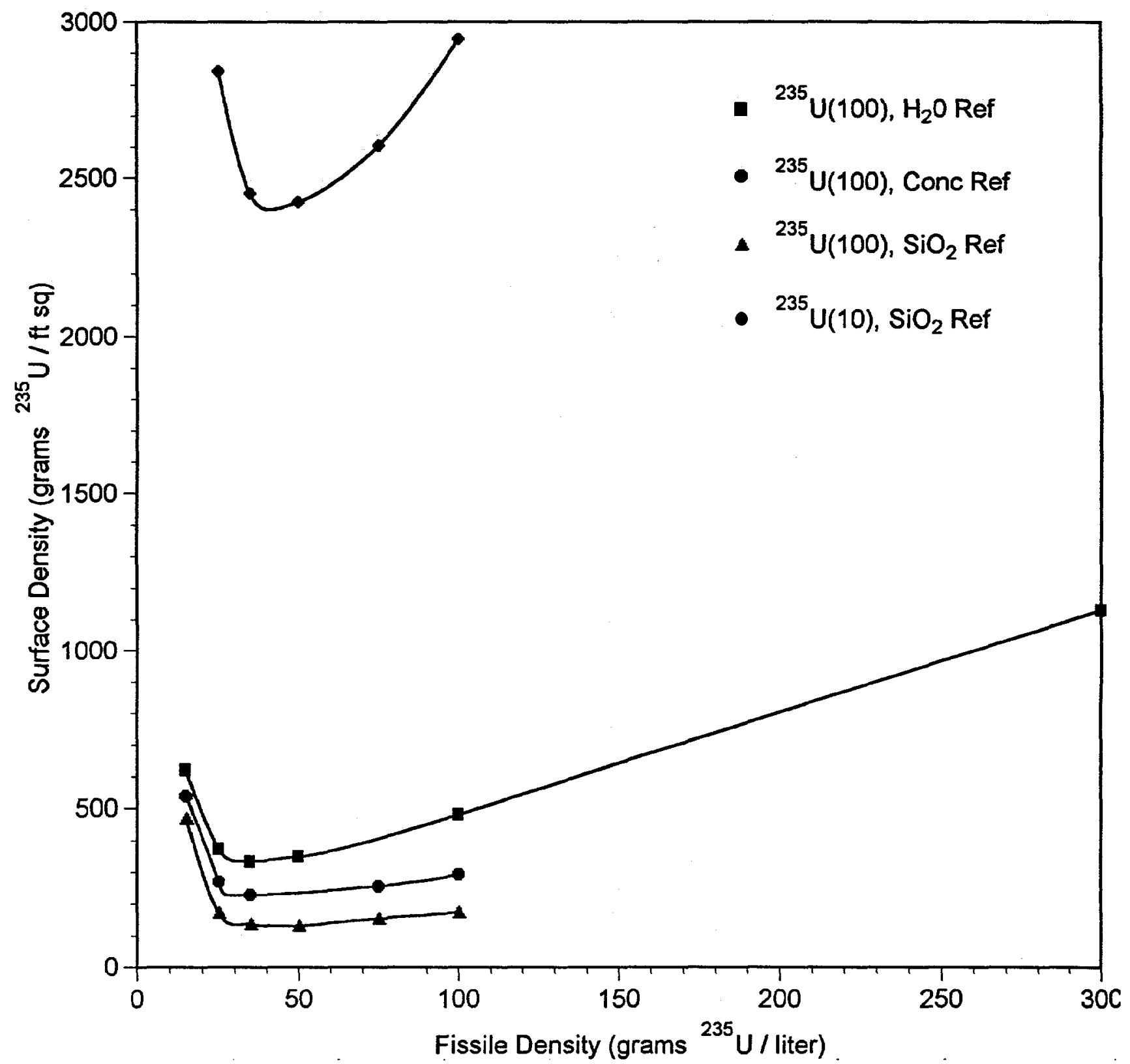

Figure 4.3 Minimum critical surface-density mass per unit area for ${ }^{235} \mathrm{U}$ units (independent of H/D ratio of single units), reflected by light water, concrete and $\mathrm{SiO}_{2}$. (Figure is based on minimum critical values taken from Tables 4.4 through 4.7.) 


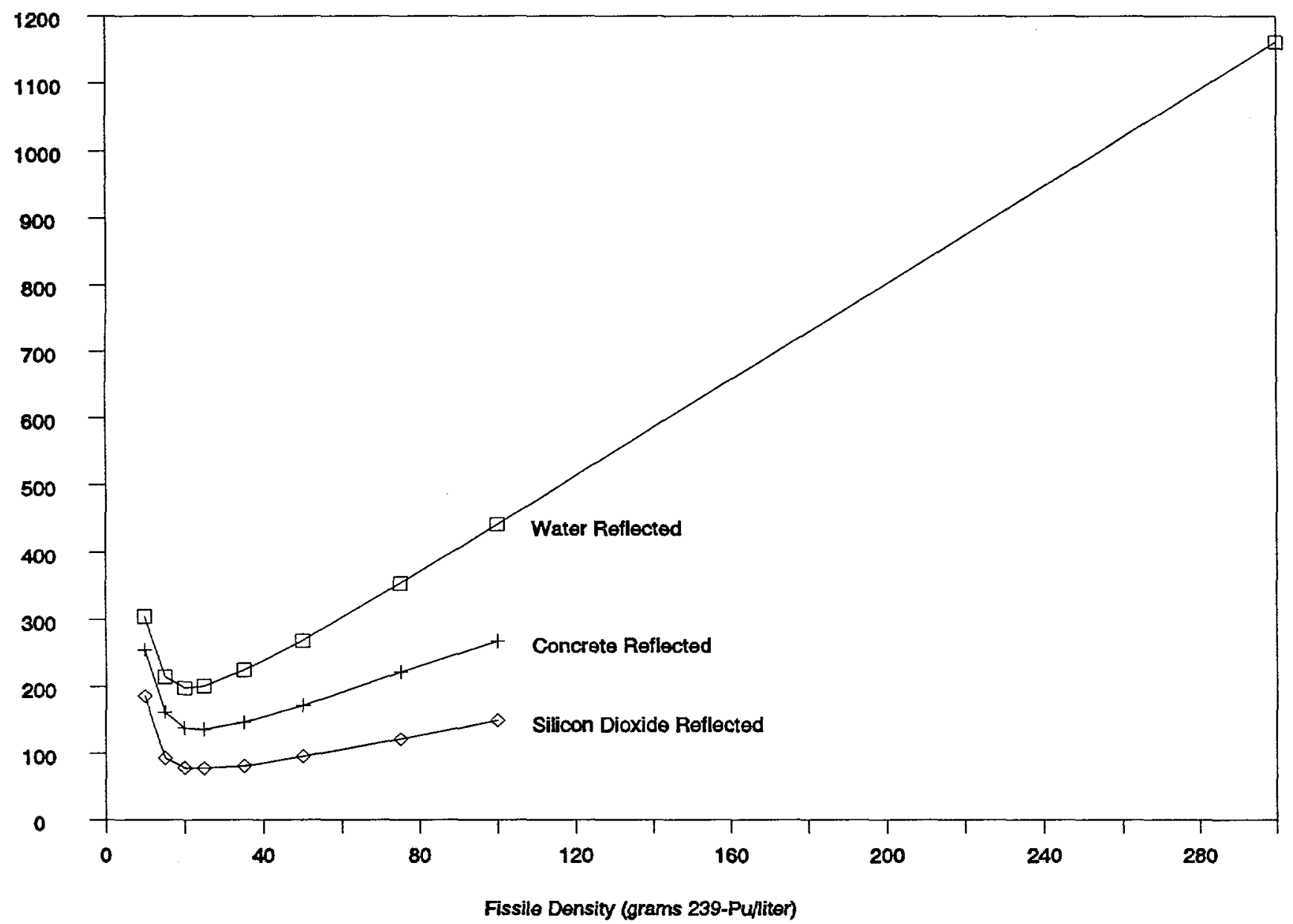

Figure 4.4 Minimum critical surface-density mass per unit area for ${ }^{239} \mathrm{Pu}$ units (independent of H/D ratio of single units), reflected by light water, concrete and $\mathrm{SiO}_{2}$. (Figure is based on minimum critical values taken from Tables 4.8 through 4.11.) 
Development

Table 4.12 ${ }^{235} \mathrm{U}(100)$ hydrogenous systems, soil $\left(\mathrm{SiO}_{2}\right)$-reflected $(\mathrm{Z}$-axis $) \mathrm{H} / \mathrm{D}=2.5$, $350 \mathrm{~g}^{235} \mathrm{U}$ per unit, $35 \mathrm{~g}^{235} \mathrm{U}$ per liter, infinite planar array

\begin{tabular}{|c|c|c|c|c|}
\hline Reflector & Pitch $(\mathrm{cm})$ & $k_{\text {eff }}$ & $\boldsymbol{\sigma}$ & {$\left[\mathrm{g}^{235} \mathrm{U} / \mathrm{ft}^{2}\right]^{\mathrm{a}}$} \\
\hline Base case, water & 31.148 & 0.9983 & 0.0019 & 335 \\
\hline Base case, concrete & 36.98 & 1.0005 & 0.0019 & 238 \\
\hline$\underset{\text { moisture }}{\mathrm{SiO}_{2} \text {, density } 1.9 ; \text { no }}$ & 46.916 & 1.0045 & 0.0020 & 148 \\
\hline $\begin{array}{c}\mathrm{SiO}_{2} \text {, density } 1.9 ; \\
\text { water saturated }\end{array}$ & 37.844 & 1.0030 & 0.0021 & 227 \\
\hline
\end{tabular}

Table 4.13 ${ }^{239} \mathrm{Pu}(100)$ hydrogenous systems, soil $\left(\mathrm{SiO}_{2}\right.$-reflected (Z-axis) $\mathrm{H} / \mathrm{D}=2.5$, $225 \mathrm{~g}^{239} \mathrm{Pu}$ per unit, $20 \mathrm{~g}^{239} \mathrm{Pu}$ per liter, infinite planar array

\begin{tabular}{ccccc}
\hline Reflector & Pitch $(\mathrm{cm})$ & $\mathrm{k}_{\text {eff }}$ & $\sigma$ & {$\left[\mathrm{g}^{239} \mathrm{Pu} / \mathrm{ft}^{2}\right]^{2}$} \\
\hline Base case, water & 32.532 & 1.0012 & 0.0019 & 198 \\
$\begin{array}{c}\text { Base case, concrete } \\
\mathrm{SiO}_{2}, \begin{array}{c}\text { density 1.9; no } \\
\text { moisture }\end{array}\end{array}$ & 38.824 & 1.0008 & 0.0019 & 139 \\
$\begin{array}{c}\mathrm{SiO}_{2}, \text { density 1.9; } \\
\text { water saturated }\end{array}$ & 50.546 & 0.9952 & 0.0021 & 82 \\
\hline
\end{tabular}

The areal density in $\mathrm{kg} / \mathrm{m}^{2}$ can be obtained by multiplying the $\mathrm{g} / \mathrm{ft}^{2}$ values by 0.010763 .

Table 4.14 ${ }^{235} U(100)$ hydrogenous systems, water-reflected (Z-axis) $H / D=2.5$, $350 \mathrm{~g}^{235} \mathrm{U}$ per unit, $35 \mathrm{~g}^{235} \mathrm{U}$ per liter, infinite planar array

\begin{tabular}{|c|c|c|c|c|}
\hline Case & Pitch $(\mathrm{cm})$ & $k_{\text {eff }}$ & $\sigma$ & {$\left[\mathrm{g}^{235} \mathrm{U} / \mathrm{ft}^{2}\right]^{\mathrm{a}}$} \\
\hline Base & 31.148 & 0.9983 & 0.0019 & 335 \\
\hline 1/4-in. $\mathrm{Pb}$, radially & 30.632 & 1.0024 & 0.0018 & 347 \\
\hline 1 -in. $\mathrm{Pb}$, radially & 30.364 & 1.0030 & 0.0020 & 353 \\
\hline 1/4-in. water, radially & 30.088 & 0.9998 & 0.0020 & 359 \\
\hline 1-in. water, radially & 22.938 & 0.9950 & 0.0019 & 618 \\
\hline $\begin{array}{l}\text { 12- gauge carbon steel, } \\
\text { radially }\end{array}$ & 26.118 & 0.9951 & 0.0020 & 476 \\
\hline 1/4-in. carbon steel, radially & 23.118 & 0.9980 & 0.0020 & 608 \\
\hline 6 -in. void on $\pm \mathrm{Z}$ axes & 31.2 & 0.9957 & 0.0018 & 334 \\
\hline $\begin{array}{l}\mathrm{SiO}_{2} \text { filling void between } \\
\text { units, dry, density } 1.9\end{array}$ & 30.916 & 0.9986 & 0.0020 & 340 \\
\hline
\end{tabular}

The areal density in $\mathrm{kg} / \mathrm{m}^{2}$ can be obtained by multiplying the $\mathrm{g} / \mathrm{ft}^{2}$ values by 0.010763 . 
Table 4.15 ${ }^{239} \mathrm{Pu}(100)$ hydrogenous systems, water-reflected (Z-axis) $\mathrm{H} / \mathrm{D}=\mathbf{2 . 5}$, $225 \mathrm{~g}^{239} \mathrm{Pu}$ per unit, $20 \mathrm{~g}^{239} \mathrm{Pu}$ per liter, infinite planar array

\begin{tabular}{lcccc}
\hline \multicolumn{1}{c}{ Case } & Pitch $(\mathrm{cm})$ & $\mathrm{k}_{\text {eff }}$ & $\sigma$ & {$\left[\mathrm{g}^{239} \mathrm{Pu} / \mathrm{ft}^{2}\right]^{\mathrm{a}}$} \\
\hline Base & 32.532 & 1.0012 & 0.0019 & 198 \\
1/4-in. Pb, radially & 32.532 & 1.0000 & 0.0020 & 198 \\
1-in. Pb, radially & 31.968 & 0.9958 & 0.0020 & 205 \\
1/4-in. water, radially & 31.264 & 1.0013 & 0.0019 & 214 \\
1-in. water, radially & 24.096 & 0.9980 & 0.0019 & 360 \\
$\begin{array}{l}\text { 12-gauge carbon steel, } \\
\text { radially }\end{array}$ & 27.432 & 1.0027 & 0.0018 & 278 \\
1/4-in. carbon steel, radially & 24.704 & 1.0046 & 0.0019 & 343 \\
6-in. void on $\pm \mathrm{Z}$ axes & 32.532 & 0.9984 & 0.0019 & 198 \\
$\begin{array}{l}\text { SiO }{ }_{2} \text { filling void between } \\
\text { units, dry, density 1.9 }\end{array}$ & 32.532 & 0.9966 & 0.0022 & 198 \\
\hline
\end{tabular}

a The areal density in $\mathrm{kg} / \mathrm{m}^{2}$ can be obtained by multiplying the $\mathrm{g} / \mathrm{ft}^{2}$ values by 0.010763 .

Table 4.16 ${ }^{235} \mathrm{U}$ and ${ }^{239} \mathrm{Pu}$ hydrogenous systems, water-reflected (Z-axis) $\mathrm{H} / \mathrm{D}=2.5,35 \mathrm{~g}^{235} \mathrm{U}$ plus ${ }^{230} \mathrm{Pu}$ per liter, infinite planar array

\begin{tabular}{ccccc}
\hline Case & Pitch $(\mathrm{cm})$ & $\mathrm{k}_{\text {eff }}$ & 0 & {$\left[\mathrm{~g}^{235} \mathrm{U}+\mathrm{g}^{239} \mathrm{Pu} / \mathrm{ft}^{2}\right]^{\mathrm{a}}$} \\
\hline $350 \mathrm{~g}^{235} \mathrm{U}(100)$, no ${ }^{239} \mathrm{Pu}$ & 31.148 & 0.9983 & 0.0019 & 335 \\
$175 \mathrm{~g}^{235} \mathrm{U}(100)$ plus & 31.52 & 0.9991 & 0.0019 & 269 \\
$112.5 \mathrm{~g}^{239} \mathrm{Pu}(100)$ & & & & \\
$225 \mathrm{~g}^{239} \mathrm{Pu}(100)$, no ${ }^{235} \mathrm{U}$ & 30.48 & 1.0049 & 0.0021 & 225 \\
\hline
\end{tabular}

${ }^{\mathrm{a}}$ The areal density in $\mathrm{kg} / \mathrm{m}^{2}$ can be obtained by multiplying the $\mathrm{g} / \mathrm{ft}^{2}$ values by 0.010763 . 
Development

Table 4.17 ${ }^{235} \mathrm{U}(100)$ hydrogenous and carbon systems, water-reflected (Z-axis) $\mathrm{H} / \mathrm{D}=2.5,350 \mathrm{~g}^{235} \mathrm{U}$ per unit, $\mathrm{H} /{ }^{235} \mathrm{U}$ atom ratio $=744$, infinite planar array

\begin{tabular}{ccccc}
\hline Carbon content & Pitch $(\mathrm{cm})$ & $\mathrm{k}_{\text {cff }}$ & $\sigma$ & {$\left[\mathrm{g}^{235} \mathrm{U} / \mathrm{ft}^{2}\right]^{\mathrm{a}}$} \\
\hline Base, no carbon & 31.148 & 0.9983 & 0.0019 & 335 \\
$5 \times$ mass ${ }^{235} \mathrm{U}$ & 31.266 & 0.9977 & 0.0020 & 333 \\
$10 \times$ mass ${ }^{235} \mathrm{U}$ & 31.068 & 0.9982 & 0.0020 & 337 \\
$20 \times$ mass ${ }^{235} \mathrm{U}$ & 31.242 & 1.0011 & 0.0019 & 333 \\
$40 \times$ mass ${ }^{235} \mathrm{U}$ & 31.508 & 0.9983 & 0.0019 & 327 \\
$80 \times$ mass ${ }^{235} \mathrm{U}$ & 32.02 & 1.0041 & 0.0018 & 317 \\
\hline The areal density in $\mathrm{kg} / \mathrm{m}^{2}$ can be obtained by multiplying the $\mathrm{g} / \mathrm{ft}^{2}$ values by 0.010763.
\end{tabular}

Table 4.18 ${ }^{235} \mathrm{U}(100)$ hydrogenous and beryllium systems, water-reflected (Z-axis) $\mathrm{H} / \mathrm{D}=2.5,350 \mathrm{~g}^{235} \mathrm{U}$ per unit, $\mathrm{H}{ }^{235} \mathrm{U}$ atom ratio $=744$, infinite planar array

\begin{tabular}{crccc}
\hline Beryllium content & Pitch $(\mathrm{cm})$ & \multicolumn{1}{c}{$\mathrm{k}_{\text {eff }}$} & \multicolumn{1}{l}{$\sigma$} & {$\left[\mathrm{g}^{235} \mathrm{U} / \mathrm{ft}^{2}\right]^{\mathrm{a}}$} \\
\hline Base, no beryllium & 31.148 & 0.9983 & 0.0019 & 335 \\
$5 \times$ mass ${ }^{235} \mathrm{U}$ & 31.766 & 1.0026 & 0.0020 & 322 \\
$10 \times$ mass ${ }^{235} \mathrm{U}$ & 32.312 & 1.0035 & 0.0018 & 311 \\
$20 \times$ mass ${ }^{235} \mathrm{U}$ & 33.480 & 1.0024 & 0.0019 & 290 \\
$40 \times$ mass ${ }^{235} \mathrm{U}$ & 34.906 & 1.0031 & 0.0018 & 267 \\
$80 \times$ mass ${ }^{235} \mathrm{U}$ & 37.356 & 0.9981 & 0.0019 & 233 \\
\hline
\end{tabular}

${ }^{2}$ The areal density in $\mathrm{kg} / \mathrm{m}^{2}$ can be obtained by multiplying the $\mathrm{g} / \mathrm{ft}^{2}$ values by 0.010763 . 
Table 4.19 Square-pitch vs triangular-pitch ${ }^{225} \mathrm{U}(100)$ hydrogenous systems, water-reflected (Z-axis) $\mathrm{H} / \mathrm{D}=2.5,350 \mathrm{~g}^{235} \mathrm{U}$ per unit, $35 \mathrm{~g}^{235} \mathrm{U}$ per liter, infinite planar array

\begin{tabular}{ccccc}
\hline Case & Pitch $(\mathrm{cm})$ & $k_{\text {eff }}$ & $\sigma$ & {$\left[\mathrm{g}^{235} \mathrm{U} / \mathrm{ft}^{2}\right]^{\mathrm{a}}$} \\
\hline Square-pitch & 31.148 & 0.9983 & 0.0019 & 335 \\
Triangular-pitch & 33.471 & 0.9967 & 0.0019 & 335 \\
\hline
\end{tabular}

" The areal density in $\mathrm{kg} / \mathrm{m}^{2}$ can be obtained by multiplying the $\mathrm{g} / \mathrm{ft}^{2}$ values by 0.010763 .

Table 4.20 Calculational uncertainties (maximum values for all calculations)

\begin{tabular}{cc}
\hline$\Delta \mathrm{k}_{\text {eff }}$ variance above 1.00 & 0.0050 \\
$2 \sigma$ (for Monte Carlo calc) $^{\prime}$ & 0.0080 \\
Cross-section uncertainty $^{7}$ & 0.0200 \\
Allowance for subcriticality & 0.0200 \\
Total & 0.0530 \\
\hline
\end{tabular}

Table 4.21 ${ }^{235} U(100)$ hydrogenous systems, water-reflected (Z-axis) $H / D=2.5$, $350 \mathrm{~g}^{235} \mathrm{U}$ per unit, $35 \mathrm{~g}^{235} \mathrm{U}$ per liter, infinite planar array (array pitch sensitivity)

\begin{tabular}{cll} 
Pitch $(\mathrm{cm})$ & $\mathrm{k}_{\text {eff }}{ }^{2}$ & $\sigma$ \\
\hline 31.148 & 0.9983 & 0.0019 \\
32.000 & 0.9839 & 0.0020 \\
34.000 & 0.9549 & 0.0020 \\
36.000 & 0.9278 & 0.0020 \\
48.000 & 0.7974 & 0.0020 \\
\hline
\end{tabular}

${ }^{2}$ Subcritical limit, $\mathrm{k}_{\text {eff }}=0.9983-0.0530=0.9453$

(based on Tables 4.19 and 4.20, were $\mathrm{k}_{\text {eff }}=0.9983$ is assumed critical) 
Development

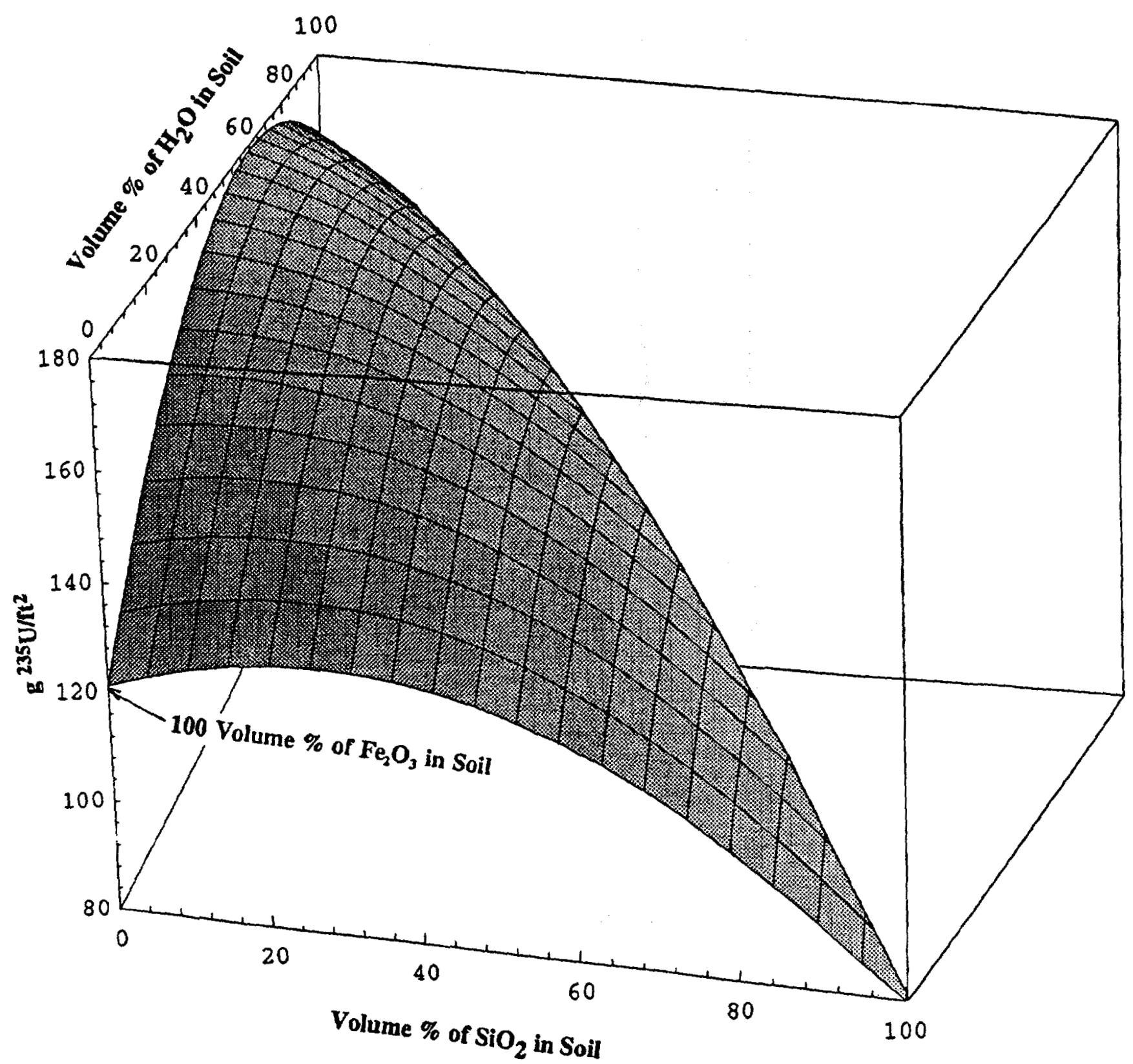

Figure 4.5 Variation of possible $U(100)$ operational areal density limits $\left(g{ }^{235} \mathrm{U} / \mathrm{ft}^{2}\right)$ vs burial trench soil composition $\left(\mathrm{Fe}_{2} \mathrm{O}_{3}, \mathrm{SiO}_{2}, \mathrm{H}_{2} \mathrm{O}\right)$ 


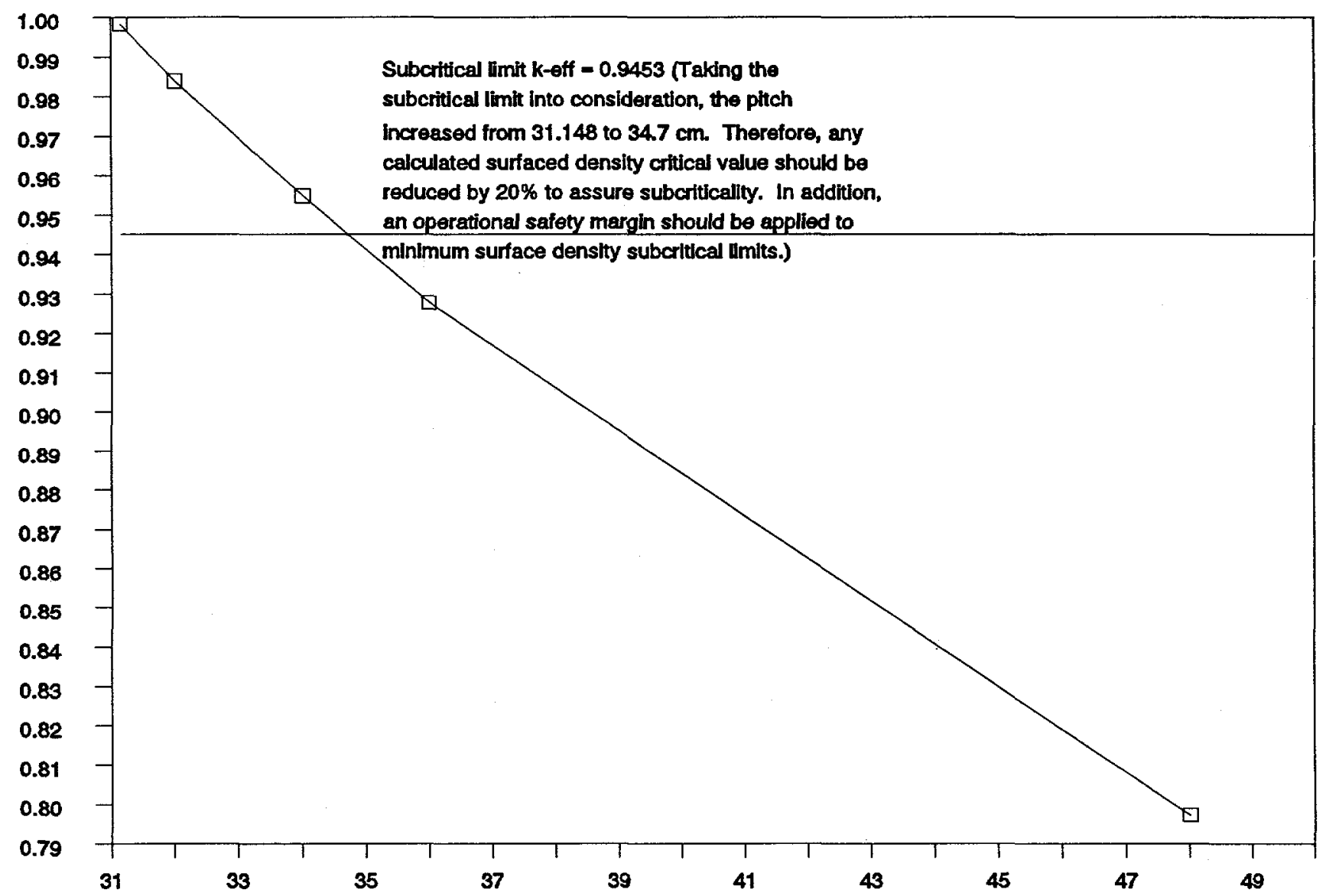

Fissile Unit Center-to-Center Spacing (square pitch), cm

Figure 4.6 Array pitch sensitivity ( $k_{e f f}$ vs pitch)

(Taken from Table $4.21,{ }^{235} \mathrm{U}(100)$ units in planar array, $35 \mathrm{~g}^{235} \mathrm{U}$ per liter, water reflected.) 


\section{DISCUSSION OF RESULTS}

Based on the data from Tables 4.4 through 4.11, the following minimum surface-density values were calculated using the SCALE code system. ${ }^{5}$ The subcritical limits were derived from the critical values by reducing the values by $20 \%$ to take into account the calculational uncertainty and applying an addi-tional $0.02 \Delta \mathrm{k}$ allowance to ensure subcriticality (see Sect. 4.10).

The array calculations using $\mathrm{SiO}_{2}$ as a reflector resulted in lower surface-density values than that anticipated prior to the analyses. Therefore, additional calculations with dry $\mathrm{SiO}_{2}$ reflectors were performed for low-enriched, homogeneous uranium systems containing $10 \mathrm{wt} \%{ }^{235} \mathrm{U}$ and $90 \mathrm{wt} \%{ }^{238} \mathrm{U}$, and homogeneous plutonium systems containing 76 wt $\%{ }^{239} \mathrm{Pu}, 12$ wt $\%{ }^{240} \mathrm{Pu}$, and 12 wt $\%{ }^{241} \mathrm{Pu}$. These isotopic compositions are expected to encompass most commercial nuclear activities and permit increased surface-density limits.

Tables 5.1 through 5.3 delineate the calculated minimum critical values, subcritical limits, and the recommended operational limits for water, concrete, and $\mathrm{SiO}_{2}$ reflected planar arrays containing ${ }^{235} \mathrm{U}$ or ${ }^{239} \mathrm{Pu}$ fissile isotopes.

For LLW packages containing ${ }^{235} \mathrm{U}$ or ${ }^{239} \mathrm{Pu}$ isotopes which are buried in soil, it is recommended that the surface-density spacing criteria be based on the operational limits, delineated in Tables 5.1 through 5.4, where $\mathrm{SiO}_{2}$ was assumed as the reflector. In addition, an operational safety margin should be applied to minimum-calculated subcritical surface-density limits. Frequently, an operational safety factor of $25 \%$ (decrease in fissile mass) would be applied to the subcritical limits.
However, actual soil will contain unquantifiable amounts of water moisture, organic materials, iron, and other materials which will absorb neutrons, thus making the array less reactive. Therefore, applying an operational safety factor of $10 \%$ to the $\mathrm{SiO}_{2}$ reflected subcritical limits is judged sufficient.

If the subcritical limits for hydrogenous and homogeneous systems containing ${ }^{238} \mathrm{U}$ or ${ }^{240} \mathrm{Pu}$ isotopes are used, then the LLW facility must take steps to ensure that the fissile material is essentially uniformly distributed throughout the package (this is not required for systems for which no credit is taken for the diluents).

For ${ }^{235} \mathrm{U}$ systems, the total mass of carbon (graphite) present in a package should not exceed 20 times the total mass of the ${ }^{235} U$ that may be present.

The effects of interspersed moderation, lead shielding, carbon steel, and dry or moist $\mathrm{SiO}_{2}$ between packages and packages on a triangular-pitch will not result in a more reactive planar array.

The calculations contain three conservative assumptions: (1) the fissile material in the waste is assumed optimally moderated, (2) the fissile material contains no absorbers, and (3) no credit is taken for the iron in the drums which is the usual method of transporting waste for disposal. It is anticipated that any iron from disintegrated containers will remain intermingled with buried LLW as iron oxide (rust). 
Table $5.1{ }^{235} \mathrm{U}(100)$ hydrogenous systems, $350 \mathrm{~g}^{235} \mathrm{U}$ per unit, infinite planar array

\begin{tabular}{cccc} 
Reflector & $\begin{array}{c}\text { Critical value } \\
{\left[\mathrm{g}^{235} \mathrm{U} / \mathrm{ft}^{2}\right]^{2}}\end{array}$ & $\begin{array}{c}\text { Subcritical limit } \\
{\left[\mathrm{g}^{235} \mathrm{U} / \mathrm{ft}^{2}\right]^{2}}\end{array}$ & $\begin{array}{c}\text { Operational limit } \\
{\left[\mathrm{g}^{235} \mathrm{U} / \mathrm{ft}^{2}\right]^{2}}\end{array}$ \\
\hline Water & 334 & 267 & 200 \\
Concrete & 227 & 181 & 135 \\
$\mathrm{SiO}_{2}$ (soil) & 132 & 105 & 94 \\
\hline
\end{tabular}

The areal density in $\mathrm{kg} / \mathrm{m}^{2}$ can be obtained by multiplying the $\mathrm{g} / \mathrm{ft}^{2}$ values by 0.010763 .

Table $5.2{ }^{235} \mathrm{U}(10)$ plus ${ }^{238} \mathrm{U}(90)$ hydrogenous and homogeneous systems $35 \mathrm{~g}^{235} \mathrm{U}$ per unit, infinite planar array

\begin{tabular}{cccc}
\hline Reflector & $\begin{array}{c}\text { Critical value } \\
{\left[\mathrm{g}^{235} \mathrm{U} / \mathrm{ft}^{2}\right]^{2}}\end{array}$ & $\begin{array}{c}\text { Subcritical limit } \\
{\left[\mathrm{g}^{235} \mathrm{U} / \mathrm{ft}^{2}\right]^{2}}\end{array}$ & $\begin{array}{c}\text { Operational limit } \\
{\left[\mathrm{g}^{235} \mathrm{U} / \mathrm{ft}^{2}\right]^{2}}\end{array}$ \\
\hline Water & not critical & 466 & 350 \\
Concrete & 390 & 312 & 234 \\
$\mathrm{SiO}_{2}$ (soil) & 242 & 193 & 174 \\
\hline
\end{tabular}

${ }^{2}$ The areal density in $\mathrm{kg} / \mathrm{m}^{2}$ can be obtained by multiplying the $\mathrm{g} / \mathrm{ft}^{2}$ values by 0.010763 .

Table $5.3{ }^{239} \mathrm{Pu}(100)$ hydrogenous systems, $225 \mathrm{~g}^{239} \mathrm{Pu}$ per unit, infinite planar array

\begin{tabular}{cccc}
\hline Reflector & $\begin{array}{c}\text { Critical value } \\
{\left[\mathrm{g}^{239} \mathrm{Pu} / \mathrm{ft}^{2}\right]^{\mathrm{a}}}\end{array}$ & $\begin{array}{c}\text { Subcritical limit } \\
{\left[\mathrm{g}^{239} \mathrm{Pu} / \mathrm{ft}^{2}\right]^{2}}\end{array}$ & $\begin{array}{c}\text { Operational limit } \\
{\left[\mathrm{g}^{239} \mathrm{Pu} / \mathrm{ft}^{2}\right]^{2}}\end{array}$ \\
\hline Water & 198 & 158 & 118 \\
Concrete & 129 & 103 & 77 \\
$\mathrm{SiO}_{2}$ (soil) & 73 & 58 & 52 \\
\hline
\end{tabular}

${ }^{2}$ The areal density in $\mathrm{kg} / \mathrm{m}^{2}$ can be obtained by multiplying the $\mathrm{g} / \mathrm{ft}^{2}$ values by 0.010763 .

Table 5.4 ${ }^{239} \mathrm{Pu}(76)$ plus ${ }^{240} \mathrm{Pu}(12)$ plus ${ }^{241} \mathrm{Pu}(12)$ hydrogenous and homogeneous systems $225 \mathrm{~g}^{239} \mathrm{Pu}$ per unit, $\mathrm{H} / \mathrm{D}=1,20 \mathrm{~g}$ Pu per liter, infinite planar array

\begin{tabular}{cccc}
\hline Reflector & $\begin{array}{c}\text { Critical value } \\
{\left[\mathrm{g}^{239} \mathrm{Pu} / \mathrm{ft}^{2}\right]^{\mathrm{a}} \text { or }} \\
\mathrm{g}\left({ }^{239} \mathrm{Pu}+{ }^{241} \mathrm{Pu}\right) / \mathrm{ft}^{2}\end{array}$ & $\begin{array}{c}\text { Subcritical limit } \\
{\left[\mathrm{g}^{239} \mathrm{Pu} / \mathrm{ft}^{2}\right]^{\mathrm{a}} \text { or }} \\
\mathrm{g}\left({ }^{239} \mathrm{Pu}+{ }^{241} \mathrm{Pu}\right) / \mathrm{ft}^{2}\end{array}$ & $\begin{array}{c}\text { Operational limit } \\
{\left[\mathrm{g}^{239} \mathrm{Pu} / \mathrm{ft}^{2}\right]^{\mathrm{a}} \text { or }} \\
\left.\mathrm{g}{ }^{239} \mathrm{Pu}+{ }^{241} \mathrm{Pu}\right) / \mathrm{ft}^{2}\end{array}$ \\
\hline $\mathrm{SiO}_{2}$ (soil) & $72(83)$ & $57(66)$ & $51(59)$ \\
\hline
\end{tabular}

The areal density in $\mathrm{kg} / \mathrm{m}^{2}$ can be obtained by multiplying the $\mathrm{g} / \mathrm{ft}^{2}$ values by 0.010763 . 


\section{REFERENCES}

1. R. L. Stevenson and R. H. Odegaarden, "Studies of Surface Density Spacing Criteria Using KENO Calculations," originally prepared circa 1970 by the Division of Materials Licensing, U.S. Atomic Energy Commission. Available as Appendix A of the Safety Evaluation Report for the Barnwell LowLevel Waste Site, License No. 12-13536-01, Amendment 23, U.S. Nuclear Regulatory Commission (April 1991).

2. Hugh C. Paxton, Correlations of Experimental and Theoretical Critical Data Comparative Reliability Safety Factors for Criticality Control, LA-2537-MS, Los Alamos Scientific Lab., March 1961.

3. H. C. Paxton, Criticality Control in Operation with Fissile material, LA-3366-Rev, Los Alamos Scientific Lab., November 1972.

4. American National Standard Guide for Nuclear Criticality Safety in the Storage of Fissile Materials, ANS-8.7 ANSI N16.5-1975 (R1987), American Nuclear Society, 1987.

5. SCALE: A Modular Code System for Performing Standardized Computer Analyses for Licensing Evaluations, NUREG/CR-0200, Rev. 4 (ORNL/NUREG/CSD-2/R4), Vols. I, II, and III (draft November 1993). Available from Radiation Shielding Information Center as CCC-545.
6. N. M. Greene, J. W. Arwood, and C. V. Parks, "The LAW Library A Multigroup Cross-Section Library for Use in Radioactive Waste Analysis Calculations," Proc. International Topical Meeting on Safety Margins in Criticality Safety, November 26-30, 1989, San Francisco, California, pp. 357-369 (1989).

7. M. D. DeHart and S. M. Bowman, Validation of the SCALE Broad Structure 44Group ENDF/B-V CrossSection Library for Use in Criticality Safety Analyses, NUREG/CR-6102 (ORNL/TM-12460), Martin Marietta Energy Systems, Inc., Oak Ridge Natl. Lab., July 1994.

8. H. C. Paxton and N. L. Pruvost, Critical Dimensions of Systems Containing ${ }^{235} \mathrm{U},{ }^{239} \mathrm{Pu}$, and ${ }^{233} U$, 1986 Revision, LA-10860-MS, Los Alamos Natl. Lab., July 1987.

9. American National Standard for Nuclear Criticality Safety in Operations with Fissionable Materials Outside Reactors, ANSI/ANS-8.1-1983, Revision of ANSI N16.1-1975, American Nuclear Society, 1983.

10. E. A. Avallone and T. Baumeister III, editors, Marks' Standard Handbook for Mechanical Engineers, 9th ed., Table p. 6-8 (Earth: Sand, gravel, dry, packed), McGraw-Hill Book Company, 1987. 
NUREG/CR-6284, ORNL/TM-12845

\section{INTERNAL DISTRIBUTION}

1. R. C. Ashline

2. S. M. Bowman

3. B. L. Broadhead

4. E. C. Crume

5. M. D. DeHart

6. H. R. Dyer

7. P. B. Fox

8. D. F. Hollenbach

9-13. C. M. Hopper

14. W. C. Jordan

15. N. F. Landers

16. B. D. Murphy

17. M. T. Naney

18. L. F. Norris

19-23. C. V. Parks
24. L. M. Petrie

25. R. T. Primm

26. C. H. Shappert

27. J. C. Turner

28. R. M. Westfall

29. G. E. Whitesides

30. R. Q. Wright

31. Central Research Library

32. ORNL Y-12 Research Library

Document Reference Section

33-34. Laboratory Records Department

35. Laboratory Records, ORNL (RC)

36. ORNL Patent Office

\section{EXTERNAL DISTRIBUTION}

37. M. G. Bailey, Office of Nuclear Material Safety \& Safeguards, U.S. Nuclear Regulatory Commission, MS TWFN 8F5, Washington, DC 20555

38. D. DeMarco, Office of Nuclear Material Safety \& Safeguards, MS TWFN 8A23, Washington, DC 20555

39. C. J. Haughney, Office of Nuclear Material Safety \& Safeguards, U.S. Nuclear Regulatory Commission, MS TWFN 8F5, Washington, DC 20555

40-59. R. C. Hogg, Office of Nuclear Material Safety \& Safeguards, U.S. Nuclear Regulatory Commission, MS TWFN 8F5, Washington, DC 20555

60. C. W. Nilsen, Office of Nuclear Material Safety and Safeguards, U.S. Nuclear Regulatory Commission, MS TWFN-9F29, Washington, DC 20555

61. R. H. Odegaarden, 6048 E. Star Valley Street, Mesa, Arizona 85205

62. Office of the Deputy Assistant Manager for Energy, Research, and Development, U.S. Department of Energy, Oak Ridge Operations (DOE-ORO), P.O. Box 2008, Oak Ridge, TN 37831

63-64. Office of Scientific and Technical Information, P.O. Box 62, Oak Ridge, TN 37831

65. R. L. Stevenson, 3726 Beazer Road, Bellingham, WA 98226

66. A. L. Thomas, Office of Nuclear Material Safety and Safeguards, U.S. Nuclear Regulatory Commission, MS TWFN-9F29, Washington, DC 20555

67. R. E. Wilson, Office of Nuclear Material Safety \& Safeguards, U.S. Nuclear Regulatory Commission, MS TWFN 8A33, Washington, DC 20555

68. C. J. Withee, Office of Nuclear Material Safety \& Safeguards, U.S. Nuclear Regulatory Commission, MS TWFN 8F5, Washington, DC 20555 


\begin{tabular}{|c|c|}
\hline 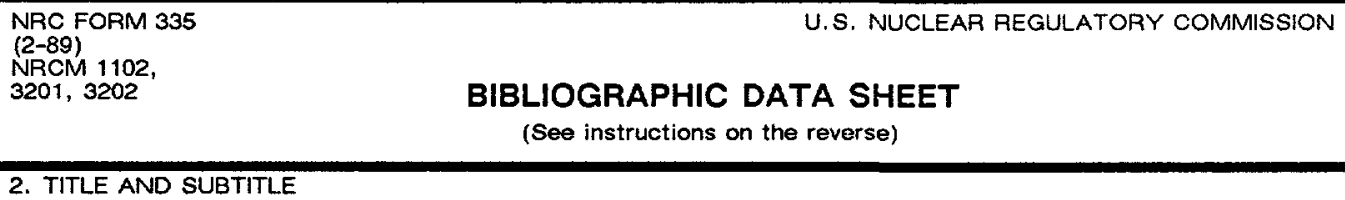 & $\begin{array}{l}\text { 1. REPORT NUMBER } \\
\text { (Assigned by NRC, Add Vol. , } \\
\text { Supp., Rev., and Addendum Num- } \\
\text { bers, if any.) } \\
\text { NUREG/CR-6284 } \\
\text { ORNL/TM-12845 }\end{array}$ \\
\hline Criticality Safety Criteria for License Review of Low-Level Waste Facilities & 3. DATE REPORT PUBLISHED \\
\hline & \begin{tabular}{l|l} 
MONTH & $\begin{array}{r}\text { YEAR } \\
1995\end{array}$ \\
March & 1995
\end{tabular} \\
\hline & $\begin{array}{l}\text { 4. FIN OR GRANT NUMBER } \\
\text { L1376 }\end{array}$ \\
\hline $\begin{array}{l}\text { 5. AUTHOR(S) } \\
\text { C. M. Hopper, R. H. Odegaarden, C. V Parks, P. B. Fox }\end{array}$ & $\begin{array}{l}\text { 6. TYPE OF REPORT } \\
\text { Technical }\end{array}$ \\
\hline & 7. PERIOD COVERED (inclusive Dates) \\
\hline
\end{tabular}

8. PERFORMING ORGANIZATION - NAME AND ADDRESS (If NRC, provide Division, Office or Region, U.S. Nuclear Regulatory Commission, and mailing address; if contractor, provide name and mailing address.)

Oak Ridge National Laboratory

Oak Ridge, TN 37831-6370

9. SPONSORING ORGANIZATION - NAME AND ADDRESS (If NRC, type "Same as above"; if contractor, provide NRC Division, Office or Region,

U.S. Nuclear Regulatory Commission, and mailing address.)

Division of Waste Management

Office of Nuclear Material Safety and Safeguards

U.S. Nuclear Regulatory Commission

Washington, DC 20555-0001

10. SUPPLEMENTARY NOTES

11. ABSTRACT (200 words or less)

This report provides recommended safety criteria for NRC licensed burial facilities. These criteria have been developed with accepted and consistent nuclear criticality safety evaluation techniques. Additionally, this report provides the bases for the recommended safety criteria by documenting the evaluation methods and assumptions, and by reporting the results of all single-package and array calculations. These criteria were developed with care to assure consistency with data and practices provided in current standards on nuclear criticality safety as well as conformity of the criteria to applicable NRC regulations.

The recommended safety criteria are expressed in terms of surface-density spacing criteria, thereby greatly simplifying the application of license conditions for nuclear criticality safety control. This approach was used by an NRC licensee at the Barnwell waste burial facility by limiting the specific controls to the fewest number of parameters consistent with good nuclear safety practice. The use of a surface-density criteria can eliminate the need for numerous license amendments for variations in package contents and specifications.

12. KEY WORDSIDESCRIPTORS (List words or phrases that will assist researchers in locating the report.)

criticality safety

low-level waste
13. AVAILABILITY STATEMENT Unlimited

14. SECURITY CLASSIFICATION

(This Page)

Unclassified

(This Report)

Unclassified

15. NUMBER OF PAGES

16. PRICE 